\title{
Global integration and emerging stock market excess returns
}

\author{
Michael Donadelli* \\ Department of Economics and Finance, LUISS Guido Carli, Rome, Italy \\ (Received 1 December 2012; final version received 24 February 2013)
}

\begin{abstract}
This article studies the effects of the global integration process on emerging stock market excess returns in a dynamic context. I improve the existing literature in four main directions. First, I show that the average excess returns rise as the level of financial and real integration rises. Second, I find overwhelming evidence that the financial liberalizations (i.e. de jure integration) of the late 1980s and early 1990s have not been simultaneously accompanied by a de facto integration. Third, I find that the percentage of variation in emerging excess returns explained by non-traded global risk factors rises as the level of market openness rises. Last, at the country level, I show that the correlation coefficient does not represent a robust measure of integration. Results also suggest that there are substantial cross-country differences in the dynamics of the degree of financial integration.
\end{abstract}

Keywords: emerging stock markets; market openness; financial integration

\section{Introduction}

The integration of international financial markets is currently a key issue in the international asset pricing literature. Many studies have observed an increasing degree of comovement between international stock markets (see Figure A.3) as well as international business cycles (see Figure 1). In recent years, particular attention has been given to the effects of stock market liberalizations on cross-country expected returns. Given the current debate on whether or not emerging markets are perfectly integrated, this article examines the dynamics of the global integration process (i.e. de facto integration) and its effects on emerging stock market prices. In my opinion, finding the answer to this question is relevant not only from a research perspective per se, but also from a practical standpoint. I analyse 28 national emerging stock markets across 5 regions (hereafter referred to as 'macro-areas'), and, for comparison purposes, the stock market of the G7 economies. I then analyse seven macro-area equal-, GDP- and trade-weighted portfolios.

The potential benefits of financial integration have been studied extensively in the economics and financial literature. Standard international asset pricing models' estimation results have largely proved that regulatory changes promoting financial and trade openness (i.e. de jure integration) tend to reduce the liberalizing countries' cost of equity capital by allowing for risk sharing between domestic and foreign agents. Most of these models have been estimated in a static context and employ pre-2005 data. In addition, a large number of papers treat stock market liberalization as a one-shot event, that is, integration occurs once a market has been liberalized. A preliminary analysis suggests that emerging stock markets have a strong time-varying component. As a consequence, estimates might be highly sample-sensitive. In particular, I observe that emerging stock

*Email: michael.donadelli@gmail.com 


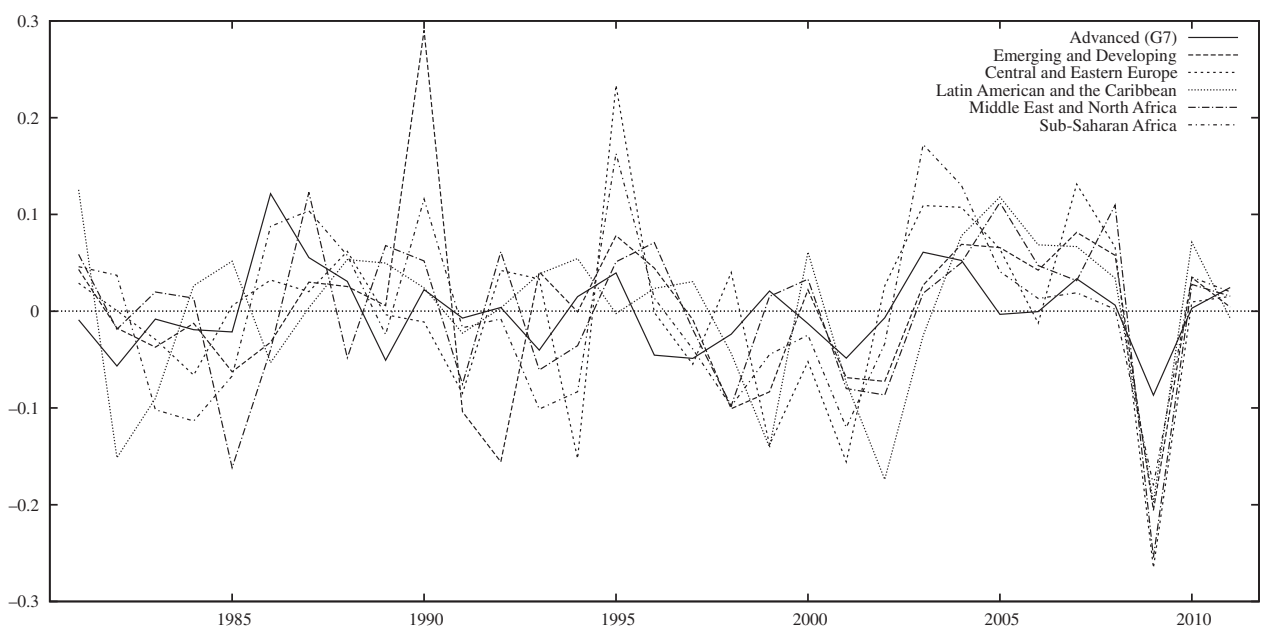

Figure 1. Cyclical components of macro area GDP annual growth rates. The time series' cyclical components are extracted via the Hodrick and Prescott (1997) method with a smoothing constant $\lambda=100$. The macro areas GDPs are based on IMF calculation. The sample goes from 1980 to 2011 . Source: IMF.

market prices have been heavily affected by local shocks. I rely on the following events: the Mexican crisis (1994), the Asian financial crisis (1997), the Russian default (1998), the Argentine economic crisis (2001), the 9/11 terrorist attacks in the US (2001) and the subprime mortgage crisis (2008). ${ }^{1}$ I argue that the existing empirical findings on the impact of financial market liberalizations on international excess returns might be 'contaminated'; that is, mainly driven by local shocks. In contrast to the existing literature, ${ }^{2}$ I use a fresh data set, which allows me to study the effects of the de jure and de facto integration on realized emerging excess returns in three relevant subperiods: (i) postliberalizations; (ii) no-crises; (iii) post-crises. ${ }^{3}$ This article is most closely related to De Jong and De Roon (2005), Donadelli and Prosperi (2012) and Pukthuanthong and Roll (2009). Similar to their empirical analysis, my environment has two key ingredients: timevarying risk sources and principal component analysis.

Using the explanatory power of a multi-(non-traded) factor model (i.e. $\bar{R}^{2}$ ) as a measure of financial integration and a proxy for the degree of market openness (i.e. trade to GDP ratio) as a measure of real integration, I obtain four main results. First, in contrast to existing empirical studies, I show that the average decrease in segmentation increases emerging excess returns. Second, I show that the removal of capital controls in emerging markets (mostly at the end of the 1980s and the early 1990s) and the de facto integration are not synchronized. Third, for the no-crises period, I show that the financial integration process and the degree of market openness move in the same direction, lowering cross-country diversification benefits, but increasing realized average excess returns. The joint analysis of Figures 1, 3, 4 and A.3 motivate my main finding. In words, the higher degree of comovement between international cycles increases the degree of comovement of international stock markets, which results in a higher percentage of variation in excess returns explained by common principal components and higher average excess returns. Fourth, at the country level and in a dynamic context, I show that the correlation between international stock market returns does not represent a robust 
measure of integration (i.e. the percentage of variation in national stock market returns that can be explained by common global factors and the correlation between them might follow different paths). The rest of the paper is organized as follows. Section 2 reviews the literature. Section 3 describes data. Section 4 analyses the impact of the increasing degree of market openness on excess returns. Using a pure rolling-window estimation scheme, I confirm the time-varying exposure of emerging stock markets to global risk factors (e.g. market factor and global integration index). Section 5 studies the dynamics of the financial integration process and its implications for emerging stock market excess returns. In a multi-factor asset pricing framework, I find that the percentage of variance in monthly excess returns explained by non-traded risk factors is heavily contingent on state and time, and increases as the degree of market openness increases. The final section concludes my article.

\section{Literature review}

The flexibility obtained in emerging equity markets through financial regulatory changes (i.e. liberalizations) has been influential for international investors. Extensive economics and financial literature addresses the potential benefits of financial integration. It is largely accepted that in opening financial markets we allow for risk-sharing between domestic and foreign investors, and this helps lower the cost of capital. A large number of studies have focused on the predictability of emerging stock returns. Results suggest that liberalizations provide evidence for having lower expected returns than that in the case of perfect segmentation. Henry (2000a) argues that in the presence of an imminent stock market liberalization, we should also see an increase in emerging countries' equity prices (i.e. demand effect). Carrieri, Errunza and Hogan (2007) observe a similar behaviour, and argue that local risk still plays an important role in explaining the time variation of emerging equity returns, suggesting that liberalization is a complex and gradual process. They also notice that the local shocks of the 1990s, such as the Argentinean, Mexican and Asian crises, might have led to inaccurate estimation results. Bekaert and Harvey (2000) point out that liberalization may not be enough to induce foreign investors to actually invest in the country. Home bias or other concerns, such as lack of information on company stocks, may impede international investment, forcing investors to ask for an extra premium (see Bekaert 1995; Levine and Zervos 1996; Donadelli and Prosperi 2012). De Jong and De Roon (2005), allowing for time variation in the integration level, find that the average annual decrease in segmentation in emerging equity markets reduces the cost of capital by about 11 basis points, and reduces stock returns by about $4.5 \%$. They associate these reductions with two types of segmentation: the level of segmentation of the country's equity market from the world market and the fall in the level of segmentation of the country's region. Carrieri, Errunza and Hogan (2007) argue that a move toward integrated markets should lower the cost of capital and increase the investment opportunity set for local and foreign investors. The benefits of financial integration have been studied also from an economic modelling point of view. For example, Colacito and Croce (2010), in a general equilibrium framework, show that closing international financial markets could result in welfare losses as large as $10 \%$ of lifetime consumption.

Given the poor empirical record of standard asset-pricing models in explaining variation in emerging stock returns, the presence of a strong time-varying component and the increasing level of market integration, the literature has also focused on richer asset-pricing models. Bilson, Brailsford and Hooper (2001), in a multi-factor framework, address the question of whether local macroeconomic variables have explanatory power 
over stock returns in emerging markets. They find weak evidence to support this argument. At the country level, via a conditional Capital Asset Pricing Model (CAPM), Donadelli and Prosperi (2012) show that global liquidity proxies (e.g. VIX and Open Interest) affect emerging market excess returns. They also show that emerging stock markets have delivered very high unexpected average excess returns in the last decade. At the industry level, Donadelli (2013) finds similar results.

Clearly, a part of the literature has focused on the dynamics of the correlation between international stock markets and asset allocation implications in an increasingly integrated environment. Early studies show that the correlation coefficients between emerging and advanced stock markets are low, and that portfolio diversification into emerging markets would provide increased returns and lower risks (see Errunza and Pabmanabhan 1988; Harvey (1993), among many others). More recent studies find that the correlations in stock returns should continue to increase as the integration proceeds in segmented markets (see Bekaert and Harvey 2002). In a time-varying framework, Bekaert, Hodrick, and Zhang (2009) find that the globalization process has not led to changes in the correlation structure across international stocks. Their findings suggest that the benefits of international diversification have persisted despite globalization. In contrast to most existing studies, Pukthuanthong and Roll (2009) show that a simple correlation between two stock markets is likely to be a poor indicator of integration. ${ }^{4}$ They argue that when there are multiple factors driving returns, such as global macro factors or even industry factors, two markets can be perfectly integrated and yet remain imperfectly correlated. The idea is that perfect integration implies that the same international factors explain $100 \%$ of the broad index returns in both countries, but if country indices differ in their sensitivities to these factors, they will not exhibit perfect correlation.

\section{Data}

\subsection{Description and preliminary analysis}

The financial data set is composed by monthly US\$-based stock returns of 28 emerging and 7 advanced national stock markets. ${ }^{5}$ I consider the point of view of a US investor who desires to allocate resources in international stock markets and is allowed to buy assets in his/her domestic currency. Note that to avoid exchange rate noise in finance, it is a common habit to convert local currency indices into a common currency. In general, national stock indices are provided by the following data providers: the International Financial Corporation (IFC), Morgan Stanley Capital International (MSCI), and INGBarings Emerging Markets Indices (BEMI). Based on a tracking error analysis, Bekaert et al. (1998) argue that IFC and MSCI are almost similar. I compute national stock returns from the Morgan Stanley Capital International Total Return Indices (hereafter MSCI TRI). The monthly stock return is given by

$$
R_{i, t}=\frac{M S C I T R I_{i, t}-M S C I T R I_{i, t-1}}{M S C I T R I_{i, t-1}}
$$

where MSCI TRI $I_{i, t}$ represents the stock market total return index level of country $i$ in period $t$. Datastream provides equity market indices for a large number of countries. For some emerging countries the total return index is not available. To have a homogeneous data set, I restrict the analysis to 28 (out of 51) markets. In contrast, the MSCI Price Index is available for a larger number of countries. Nevertheless, the former is preferable, as 
Table 1. Morgan Stanley Capital International: Total Return Index. All MSCI TRIs are denominated in US dollars. The sample period goes from January 1988 (or later) to December 2011. Datastream mnemonic for each country contains the following designations: 'TRI' (i.e. reinvested dividends) and ' U\$' (i.e. the original local currency equity index is converted in US dollars with the Datastream exchange rate conversion facility). The coverage in time is limited. Data starting point limits: Colombia, Peru, Poland, China, India Pakistan, Sri Lanka and South Africa (from January 1993); Czech Republic, Hungary, Russia and Egypt (from January 1995); Kenya and Nigeria (from June 2002); Morocco and Tunisia (from June 2004).

\begin{tabular}{|c|c|c|c|c|c|}
\hline $\begin{array}{l}\begin{array}{l}\text { Developed } \\
\text { countries }\end{array} \\
\text { Advanced }\end{array}$ & $\begin{array}{c}\begin{array}{c}\text { Emerging } \\
\text { countries }\end{array} \\
\text { Latin America }\end{array}$ & Eastern Europe & Asia \& FE & $\begin{array}{c}\text { Sub-Saharan } \\
\text { Africa }\end{array}$ & $\begin{array}{c}\text { North Africa \& } \\
\text { ME }\end{array}$ \\
\hline $\begin{array}{l}\text { Canada } \\
\text { France } \\
\text { Germany } \\
\text { Italy } \\
\text { Japan } \\
\text { United Kingdom } \\
\text { United States }\end{array}$ & $\begin{array}{l}\text { Argentina } \\
\text { Brazil } \\
\text { Chile } \\
\text { Colombia } \\
\text { Mexico } \\
\text { Peru }\end{array}$ & $\begin{array}{l}\text { Czech Republic } \\
\text { Hungary } \\
\text { Poland } \\
\text { Russia } \\
\text { Turkey }\end{array}$ & $\begin{array}{l}\text { China } \\
\text { India } \\
\text { Indonesia } \\
\text { Korea } \\
\text { Malaysia } \\
\text { Pakistan } \\
\text { Philippines } \\
\text { Sri Lanka } \\
\text { Taiwan } \\
\text { Thailand }\end{array}$ & $\begin{array}{l}\text { Kenya } \\
\text { Nigeria } \\
\text { South Africa }\end{array}$ & $\begin{array}{l}\text { Egypt } \\
\text { Jordan } \\
\text { Morocco } \\
\text { Tunisia }\end{array}$ \\
\hline
\end{tabular}

Source: Datastream.

long as it includes reinvested dividends. Table 1 lists all the countries for which the MSCI TRI is downloaded. Excess returns in Equation (2) are trivially computed by subtracting from Equation (1) a risk-free rate proxy. Formally,

$$
\operatorname{ExR}_{i, t}=R_{i, t}-R_{t}^{f}
$$

where $R_{t}^{f}$ is the one month Treasury-bill from the Kenneth French Data Library.

In the most recent financial literature a similar data set has been widely used (see Bekaert and Harvey 1995; Bekaert, Harvey, and Lundblad 2003; Carrieri, Errunza, and Hogan 2007; Donadelli and Prosperi 2011; Estrada 2000; Grootveld and Salomons 2003; Panchenko and Wu 2009; Pukthuantong and Roll 2009; Gau, Mingshu, and Wu 2010, among others). Other empirical works, which focus on emerging stock markets, have also used data from the Emerging Markets Database of the International Finance Corporation (see Bekaert and Harvey 1997; Bekaert et al. 1998; Carrieri, Errunza, and Hogan 2007; Chari and Henry 2004; De Jong and De Roon 2005; Donadelli and Prosperi 2012; Henry 2000a, 2000b, among others). In contrast to past empirical findings, my data set allows us to deeply study the behaviour of emerging stock markets during the last decade, and in particular during the last five years (i.e. during the subprime mortgage credit crisis).

Monthly summary statistics of countries' excess returns are presented in Table A.2. Some empirical regularities on emerging equity markets are confirmed: high returns, high volatility and increasing correlation between emerging and advanced markets. ${ }^{6}$ The average excess return across emerging and advanced equity markets is equal to $1.30 \%$ and $0.42 \%$, respectively. Most of the advanced economies display monthly excess returns below the $1.0 \%$ level. In Japan the average excess return in negative (i.e. $-0.12 \%$ ). In contrast, I observe monthly average excess returns above or largely above the $1 \%$ level in 
19 out of 28 emerging markets. Such a gap is confirmed when stock market performances are measured per unit of risk. The average Sharpe ratio (defined as the ratio of the average excess return to its standard deviation) in emerging and advanced markets is close to 0.12 and equal to 0.08 , respectively. In Figure A.3, I report the rolling correlation coefficients between the emerging national stock markets and the US stock market. As expected, correlation coefficients tend to increase over time, and are rarely negative. A sharp increase in the correlation coefficients between emerging and US stock markets during the last recession is evident. The result is related to the concept of contagion (i.e. a negative event does not remain confined to where it is generated, but tends to spread somewhere else) (see Corsetti et al. 2005). I also observe that correlations tend to increase more in the no-crises period (i.e. between the last two NBER-dated recessions). In general, my monthly statistics seems to support many observed empirical regularities on emerging national stock market excess return, and provide an updated analysis on the behaviour of international excess returns.

\subsection{Macro portfolios: construction and methodology}

In addition to individual country data, I aggregate data in seven different macro areas as follows: Latin America (6 countries), Eastern Europe (5 countries), Asia (10 countries), Sub-Saharan Africa (3 countries), North Africa \& Middle East (4 countries), Emerging (28 countries) and Advanced (7 countries). The sample period goes from January 1988 (or later) to December 2011. I construct the seven macro area portfolios following the above geographical aggregation (see Table 1). Three different types of portfolios are constructed: equal-, GDP- and trade-weighted. In practice, I create seven different time series. Each time series represent the excess return of the macro area portfolio, computed as the weighted average of the excess returns of all the national stock market excess returns belonging to the same region (i.e. macro area). Hence, weights are equal across countries, computed as the share of country total trade over the total trade of the macro area and as the share of country Nominal GDP over the macro area Nominal GDP. The International Monetary Fund (IMF) provides the Gross Domestic Product (GDP) time series at a yearly frequency for each country. ${ }^{7}$ Data are at current prices and denominated in US\$. ${ }^{8}$ The total GDP of a macro area is simply the sum of the GDP of the countries composing the area. International total trade series are computed as the sum of imports and exports of goods. Nominal Data on imports and exports of goods are from Global Financial Data (GFD) and available on a monthly basis from the 1950s. Data are denominated in US\$ and adjusted seasonally. As for the total GDP, the total trade of a macro area is simply the sum of the imports and exports of goods of all the countries in the macro area. Let $j$ be the subscript representing the macro area, $i$ the subscript denoting a specific country $i$ in a specific macro area $j$ and $N$ the total number of countries composing each macro area $j$. Formally, the portfolios can be defined as in Equations (3)-(5),

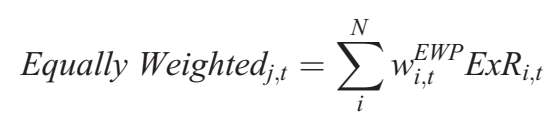

where

$$
w_{i, t}^{E W P}=\frac{1}{N}
$$




$$
G D P \text { Weighted }_{j, t}=\sum_{i}^{N} w_{i, t_{12}}^{G D P} \operatorname{ExR}_{i, t}
$$

where

$$
\begin{aligned}
& w_{i, t_{12}}^{G D P}=\frac{G D P_{i, t_{12}}}{\sum_{i}^{N} G D P_{i, t_{12}}}, \\
& \operatorname{TRADE}_{\text {Weighted }_{j, t}}=\sum_{i}^{N} w_{i, t}^{T R A D E} \operatorname{ExR}_{i, t}
\end{aligned}
$$

where

$$
w_{i, t}^{T R A D E}=\frac{T R A D E_{i, t}}{\sum_{i}^{N} \operatorname{TRADE} E_{i, t}} .
$$

To match the IMF GDP data frequency, the GDP-weighted portfolios are rebalanced on a yearly basis. I assume that an investor observes at the beginning of each year the GDP realized in the previous year. The investor then constructs the portfolio according to Equation (4). Country weights are then kept constant for 12 months, as indicated by the subscript ' 12 ' in Equation (4). Given that data on import and exports of goods are monthly available, the trade-weighted and the equal-weighted portfolios are rebalanced on a monthly basis. For simplicity, I assume that an investor can observe both stock and trade data simultaneously at the end of each month, and he/she forms weights according to Equation (5). In case of missing observations, the weight is assumed to be constant (i.e. equal to the previous month of any missing observations). ${ }^{9}$ Because data on MSCI TRI do not start simultaneously, as data become available, countries are added to the portfolios. For this reason, in extreme cases an investor can only invest $100 \%$ in a single stock market. Monthly summary statistics for the equal-, GDP- and trade-weighted macro area portfolio excess returns are reported in Table A.3.

\subsection{A proxy for the degree of market openness}

To capture the degree of market openness, I use a very simple and common proxy: the global trade to GDP ratio (i.e. global integration index). This measure as well as its effects on international development have been extensively used in the literature (see De Jong and De Roon 2005; Liao and Santacreu 2012; Santacreu 2011, among many others). A difference measure has been proposed by Bekaert (1995) and Edison and Warnock (2003). In particular, they propose a measure based on the market capitalization of the firms constituting the IFC Investable Index to those that constitute the IFC Global Index for each country, where the former is supposed to represent the part of domestic equities that are available to foreign investors. It is also widely accepted that financial openness stimulates economic growth. For example, Bekaert et al. (2003) find that official liberalizations generate an increase in average annual per capita GDP of around $1 \%$. Nevertheless, such measure reflects de jure integration. The purpose of this article is to capture de facto integration and its impact on emerging stock prices. Therefore, in the presence of a higher degree of comovement between business cycles and of a large 
literature arguing that bilateral trade is key for global growth, a real measure seems to be more consistent. In this article, global trade is represented by the sum of all regions' trade (i.e. sum of all imports and exports of goods), and the global GDP is given by the sum of all OECD members GDPs (i.e. Equation (6)). ${ }^{10}$ All variables are denominated in US\$. Since OECD data can be observed only on a quarterly basis, the denominator of the global integration index is assumed to be fixed within a quarter (as indicated by the subscript $t_{4}$ ). In contrast, the numerator varies on monthly basis. Trade data are from Global Financial Data and national accounts data are from OECD database.

Formally:

$$
\text { Global Integration Index }=\frac{\sum_{j, t} T R A D E_{j, t}}{\sum_{k, t_{4}} G D P_{k, t_{4}}}
$$

where $t$ ranges from January 1988 to September 2011 and $t_{4}$ ranges from 1987:4Q to 2011:2Q. The subscripts $j$ and $k$ represent the region (i.e. macro area) and the OECD member, respectively.

\section{The effect of global integration on excess returns}

\subsection{On the financial and economic integration}

Financial market liberalizations, globalization of trade and companies, the higher correlation between international business cycles (see Figure 1), the higher degree of comovements between international stock markets (see Figure A.3) and the rapid development of emerging markets during the last two decade have brought a major challenge to the financial world. The progressive integration of international financial and real markets have forced international investors to re-design portfolio strategies, and researchers to modify international business cycle models, adopt different estimation techniques and employ global rather than local information variables to predict emerging stock returns. The effect of the globalization of capital markets on emerging stock prices (i.e. cost of capital and expected returns) is not a simple matter. As noticed by Stulz (1995), the global integration of markets might have two directly opposite effects on the cost of equity capital: (i) it decreases because the risk premium can be shared among a larger number of investors; (ii) it increases because greater correlation among national stock markets reduces diversification benefits. While many works have studied financial reforms (i.e. de jure integration) and their effects on international stock market prices, few works have been devoted to study the nature of the real and financial integration processes as well as their implications for the predictability of emerging stock returns, the dynamics of the correlation between international stock markets and the propagation of isolated shocks. On one hand, a unique measure of real and financial integration does not exist. For example, real economic integration has been measured in many ways. Frequent measures include the degree of openness calculated as the ratio of exports and/or imports between countries to national output; the amount of price and quantitative restrictions on traded goods; and the extent of contemporaneous movement of output growth between countries. Furthermore, the debate about the proper measure of financial openness is still open. For many years the simple correlation between emerging and advanced stock market returns has been used to measure financial integration. However, more recent studies show that the correlation is a poor measure of global market integration. At the same time, emerging stock markets present a strong time-varying component and have been affected by many 
bank crises. Hence, time variation in the level of market segmentation is important and should be taken into account in the estimation of the impact of liberalizations on the cost of capital (i.e. time-varying integration implies time-varying expected returns). Given the current scenario, the most recent literature has focused on the predictability of emerging stock returns and on the study of a proper measure of financial integration. To predict excess returns, Bekaert and Harvey (2000) use the country's market capitalization to GDP and the trade to GDP ratios as measures for economic integration. Similarly, to estimate the effect of market segmentation on expected returns, De Jong and De Roon (2005) augment the pricing equation of the ICAPM with the ratio of non-investable market value to total market value. They show that this measure of market segmentation varies through time. To capture the market integration process, Carrieri, Errunza, and Hogan (2007), Pukthuanthong and Roll (2009), and Kritzam et al. (2011) have proposed alternative measures of integration. They all agree that international markets have become increasingly integrated. Nevertheless, the debate about whether or not emerging markets are perfectly integrated is still open. For example, Bekaert, Harvey, Lundblad and Siegel (2009) find that the segmentation has significantly trended downward through time for both developed and emerging markets. However, they also find that segmentation across emerging markets is still significant (i.e. only developed markets are effectively integrated). Using the global trade to GDP ratio as a measure of market openness, I show that the exposure to real integration is heavily time-varying. In particular, I find that estimation results are heavily sample sensitive. First, in a conditional two-factor CAPM framework, I show that market openness affects both the emerging excess returns and the market price of risk. Nevertheless, the sign of the sensitivity to the degree of market openness changes over time. Second, in a standard one-factor model framework, I find that the exposure to the global integration index is increasing over time.

\subsection{A standard asset pricing model}

In this short section, I confirm that the variability in segmentation of emerging markets translates into time variation in expected returns. Via a conditional CAPM, I show that the degree of market openness affects both the average excess returns and the market price of risk. I run the following regression,

$$
R i, t-R_{t}^{f}=\alpha_{i}+\beta_{i, m}\left(R_{m, t}-R_{t}^{f}\right)+\varphi_{i}\left[\left(R_{m, t}-R_{t}^{f}\right) \cdot\left(\text { GlobIntIndex }_{t-1}\right)\right]+\varepsilon_{i, t}
$$

where $R_{i, t}-R_{t}^{f}$ denotes the excess return of the macro-area portfolio (or country) $i$, $R_{m, t}-R_{t}^{f}$ is the US dollar return of the MSCI world market equity index (i.e. MSCI TRI) in excess of a short term interest rate (i.e. one month T-bill), and GlobIntIndex is the proxy for the degree of market openness, computed as in Equation (6). ${ }^{11}$ Estimation results are based on two different samples: (a) the largest data set available (i.e. from January 1988 to December 2011); (b) a restricted sample (i.e. from January 1995 to December 2011). The latter represent the post-liberalizations sample. ${ }^{12}$ Estimates of Equation (7), for these two samples, are reported in panels A and B of Tables B.1 and B.2. As expected, most emerging market betas are significantly different from zero, and often significantly larger than one. ${ }^{13}$ In most markets, the excess return is significantly affected by the degree of market openness. For the post-liberalizations sample, the effect of integration is stronger. The estimated coefficients, $\varphi_{i} s$, are statistically different from zero in five out of six portfolios. The result holds for the equal-, GDP- and trade-weighted 
portfolios. I confirm that the effects of integration on excess returns are statistically and economically significant (see De Jong and De Roon 2005). I stress that all the integration coefficients are negative (i.e. to an increase in the level of integration corresponds a decrease in the average excess returns' level). Weak estimates are obtained only for the North African \& Middle East portfolio. Similar estimates for $\varphi_{i}$ are obtained in the country-by-country analysis. Table B.2 (panel B) shows that the interaction effect coefficient is statistically significant and negative in 18 out of 28 markets over the postliberalizations period. My findings broadly confirm that integration provides two opposite effects on excess returns. As suggested by De Jong and De Roon (2005), if integration took place, I should expect simultaneously a positive and negative effect on excess returns. The former is due to the fact that market betas increase with the decrease in the segmentation level. In line with the main idea of this article, I show that the results illustrated in panels A and B of Tables B.1 and B.2, are heavily state- and time-dependent. As an exercise, I replicate the analysis using a restricted sample running from January 2002 to August 2008 (i.e. no-crises sample). In the rest of the article, I refer to this sample only graphically, relying on the sample bounded by the last two NBER-dated recessions. Results are illustrated in panel C. I find that the degree of market openness positively affects average excess returns (i.e. positive $\varphi_{i} s$ ). Estimates are statistically significant in six out of seven portfolios and in nine countries. Small movements along the restricted sample preserve the results. I summarize the empirical findings as follows: (i) I show that average excess returns increase with increasing degree of market openness; (ii) I find that the collapse in the average excess returns is mainly caused by financial shocks (i.e. emerging crises). The joint analysis of Figures A.1, A.2 and C.1 confirms these two results. It clearly emerges that emerging average excess returns as well as Sharpe ratios are increasing in the no-crises sample. It turns out that emerging markets display higher performances during periods of increasing market openness.

\subsection{The time-varying risk exposure: some stylized facts}

It is popularly believed that the increase in integration has decreased the cost of capital in many emerging markets (see Bekaert and Harvey 2000; Henry 2000a, 2000b, among others). De Jong and De Roon (2005) claim that most of the literature on capital market openness treats liberalization as a one-shot event and assumes that markets are largely isolated before the official liberalization date, and perfectly integrated after that date. In a pure time-varying setup, I confirm that the integration process is a dynamic concept and heavily affects average excess returns. I run two different sets of one-factor rolling regressions. In the first set, I replicate the one-factor market model (or world CAPM), borrowing the excess return of the market portfolio from the Kenneth R. French Data Library. For the second set of rolling regressions (one-factor trade model), I assume that the integration index, as defined in Equation (6), is freely tradable. Hence, the rate of return of the integration index is used as a global risk factor. For space reasons, I report estimation results based on equally weighted portfolios only. Estimates based on GDPand trade-weighted portfolios are almost identical. During the late 1990s market betas seem to follow an increasing path in all emerging areas. This confirms the key role played by domestic shocks. Instead, between 2000 and 2007, market betas decrease (see top right panel of Figure 2), lowering average excess returns. Figure 2 suggests that the exposure of emerging stock markets to global factors is heavily time-varying. In all graphs the dotted black line represents the advanced portfolio. 

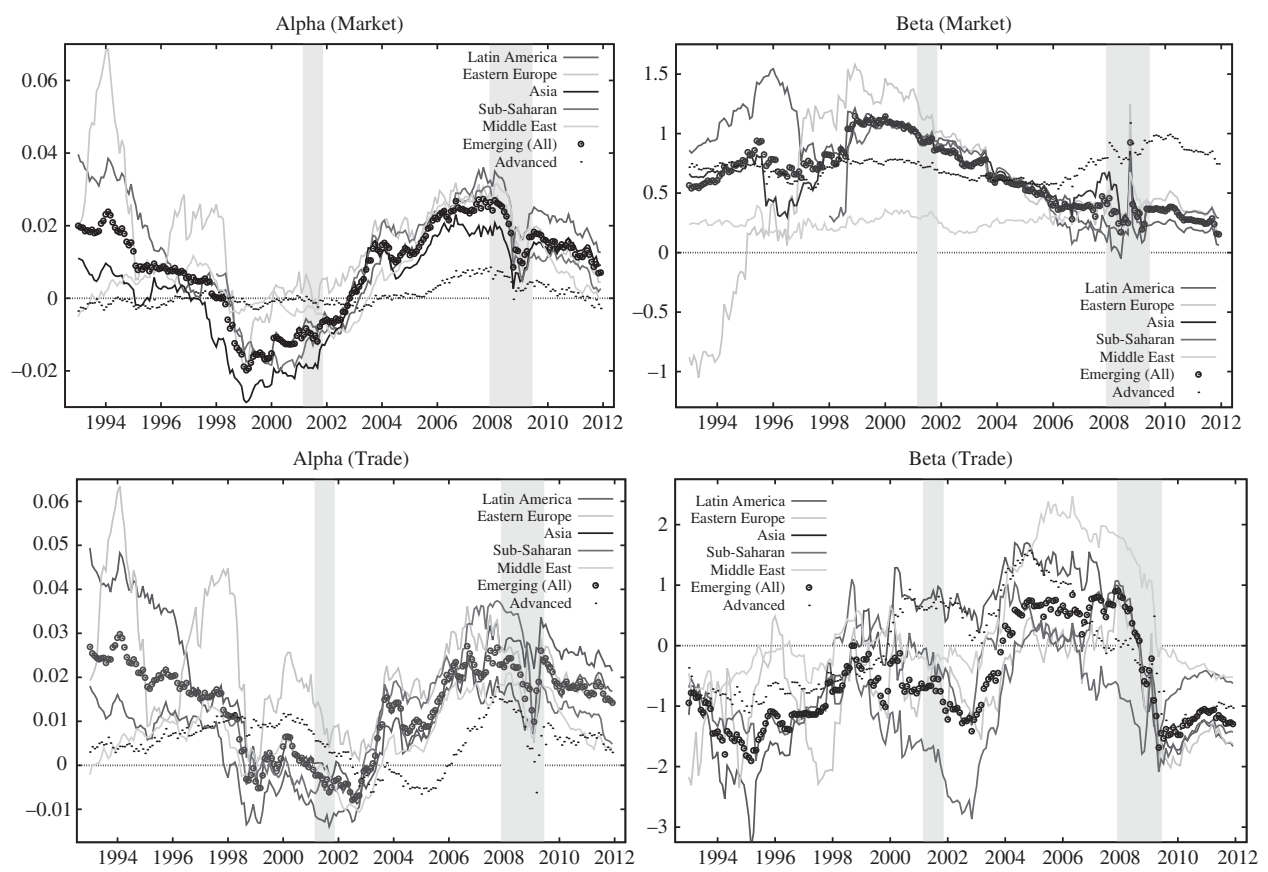

Figure 2. This figure reports the dynamics of the alphas and betas estimated via the following two different one-factor linear models:

$$
R_{i, t}-R_{t}^{f}=\alpha_{i}^{m k t}+\beta_{i, m k t}\left(R_{m k t, t}-R_{t}^{f}\right)+\varepsilon_{i, t}^{m k t} \text { (one-factor market model, top panel) }
$$

$$
R_{i, t}-R_{t}^{f}=\alpha_{i}^{\text {trade }}+\beta_{i, \text { trade }}(\Delta \text { GlobIntIndex })+\varepsilon_{i, t}^{\text {trade }} \text { (one-factor trade model, bottom panel) }
$$

where $R_{m k t, t}-R_{t}^{f}$ is the excess return of the market portfolio from the Kenneth R. French Data Library and $\Delta$ GlobIntIndex is the rate of change of the global integration index, defined as in Eq. (3.6). Estimated values are obtained using a rolling window of 60 months. Standard errors are Newey-West (1987). One-factor market model: the sample goes from January 1988 (or later) to December 2011 (228 windows). One-factor trade model: the sample goes from January 1988 (or later) to September 2011 (225 windows). Note: the shaded vertical bars in all graphs denote NBERdated recessions.

Source: Datastream, IMF and Global Financial Data.

As expected, the fluctuations of the estimated values of the mature portfolio are very small. One common feature of emerging markets is that they usually display an unstable industrial structure. Empirical evidence is given in Table 2. I find that the volatilities of the estimated alphas and betas are higher in the emerging economies. I also find that impact of the rate of growth of the trade index on international excess returns is extremely large. Trade betas range from -3 to 2.5 , roughly. It turns out that the volatility of the estimated trade betas is high in all portfolios. It ranges from $6.07 \%$ (i.e. Sub-Saharan) to $12.70 \%$ (i.e. Latin America). In particular, I observe that the exposure to the market openness' growth rate is heavily increasing during the no-crises period, both in emerging and advanced portfolios. In contrast, over the same period, the exposure to the standard 
Table 2. This table reports the standard deviation (i.e. volatility) of the estimated intercepts (i.e. alpha) and risk quantities (i.e. betas), for two different one-factor linear models:

$$
\begin{gathered}
R_{i, t}-R_{t}^{f}=\alpha_{i}^{m k t}+\beta_{i, m k t}\left(R_{m k t, t}-R_{t}^{f}\right)+\varepsilon_{i, t}^{m k t} \text { (one-factor market model, PANEL A) } \\
R_{i, t}-R_{t}^{f}=\alpha_{i}^{\text {trade }}+\beta_{i, \text { trade }}(\Delta \text { GlobIntIndex })+\varepsilon_{i, t}^{\text {trade }}(\text { one-factor trade model, PANEL B) }
\end{gathered}
$$

where $R_{m k t, t}-R_{t}^{f}$ is the excess return of the market portfolio from the Kenneth $\mathrm{R}$. French Data Library and $\Delta$ GlobIntIndex is the rate of change of the global integration index, defined as in Eq. (3.6). Estimated values are obtained using a rolling-window of 60 months. Standard errors are Newey-West (1987). Standard deviations are computed over the number (i.e. number of windows) of estimated values. Volatilities are expressed in percentage points. One-factor market model: the sample goes from January 1988 (or later) to December 2011 (228 windows). One-factor trade model: the sample goes from January 1988 (or late) to September 2011 (225 windows).

\begin{tabular}{lccccccr}
\hline Estimates & LatAm & EastEu & Asia & SubSah & MidEast & Emerg & Adv \\
\hline PANEL A: & & & & & & & \\
Alpha (Mkt) & 1.58 & 1.51 & 1.39 & 1.51 & 1.08 & 1.26 & 0.29 \\
Beta (Mkt) & 4.05 & 5.93 & 2.55 & 3.22 & 0.82 & 2.63 & 1.10 \\
PANEL B: & & & & & & & \\
Alpha (Trade) & 1.47 & 1.26 & 1.07 & 1.32 & 0.74 & 0.99 & 0.53 \\
Beta (Trade) & 12.70 & 7.69 & 8.90 & 6.07 & 9.23 & 7.82 & 7.96 \\
\hline
\end{tabular}

market factor is decreasing. As expected, emerging market betas are increasing and, on average, higher than one during the 1990s. These dynamics confirm the state-contingent nature of the estimates as well as the presence of 'contaminated' results obtained in past empirical findings. In addition, I argue that increasing trade betas reflect consumptionsmoothing motive. In a consumption-based context, the trade factor represents an indicator of the state of the economy. Assets that pay off in future states when the marginal utility of consumption is low - when the economy is doing well (i.e. trade index increases) - are less desirable. To hold such assets, investors required to be compensated (i.e. higher average excess returns).

\section{A robust measure of integration}

Recent studies point out that the simple correlation between different national stock index returns represents a poor measure of integration (see Carrieri, Errunza, and Hogan 2007); Pukthuanthong and Roll 2009, among others). Most of these studies have been devoted to finding a proper measure of integration and to analyse its evolution. However, the effectiveness of the evolution of the global integration process on emerging stock market prices has rarely been discussed. This section has two main goals. First, in the spirit of Pukthuanthong and Roll (2009), I measure financial market integration via the $\bar{R}^{2}$ of a multi-(non-traded) factor model. In a rolling-window estimation scheme, the estimated $\bar{R}^{2} s$ define the dynamics of the financial integration process. Second, I study the effects of changes in the degree of market segmentation on emerging stock market excess returns. Non-traded factors are artificially obtained via PCA. The purpose of the PCA is to condense the variables that explain the return variation in each national stock market 
into a smaller set of common risk sources (i.e. factors). In particular, I extract the principal components using two different approaches, namely 'standard' and 'global,' respectively. The standard approach is most closely related to Pukthuanthong and Roll (2009). As in their PCA, I extract principal components from a data set composed by excess returns only. In the global approach, I extract principal components from a data set composed by leading global economic indicators. In both approaches, my PCA differs from Pukthuanthong and Roll (2009) in two main directions. ${ }^{14}$ First, I employ the correlation matrix. This procedure effectively gives each variable an equal weighting in the data matrix, independent of their variance, and avoids loading on those variables with the largest standard deviation. Second, the correlation matrix is constant. In practice, I estimate the principal components from excess returns only once. The resulting principal components represent my non-traded factors.

\subsection{The standard approach}

At the beginning of my sample, 19 national stock markets are available. I use these 19 national stock market excess returns to perform the PCA. ${ }^{15}$ It is common practice to use, as proxies for the global risk factors, the first 10 principal components, which generally account for $90 \%$ of the cumulative eigenvalues. The first 10 principal components represent the risk sources of the multiple beta model. The multi-(non-traded) factor model is shown in Equation (8)

$$
\operatorname{ExR}_{j, t}^{w}=\alpha_{j}^{w}+\sum_{c=1}^{10} \psi_{c}^{w} G R F_{c, t}^{w}+\varepsilon_{j, t}^{w}
$$

where $j$ represents the macro area portfolio excess return (or national stock market excess return), $c$ is the number of principal components, $w$ denotes the estimation window and $\varepsilon_{j, t}^{w}$ is the error term. The intercept, $\alpha_{j}^{w}$ ('PCA alpha'), measures the monthly average unexpected excess returns (i.e. Jensen's alpha). I am interested in the dynamics of the $\bar{R}^{2}$ as well as in the dynamics of the intercept.

\subsubsection{On the $\bar{R}^{2}$}

Figure 3 plots the dynamics of the $\bar{R}^{2}$ for the macro area portfolios. The cross-country average $\bar{R}^{2} s$ and the annual rate of growth of the average $\bar{R}^{2} s$ are also reported. For space reasons, I report estimation results for the equally weighted portfolios only. GDP- and trade-weighted estimates are almost identical. My main empirical findings are: (i) during the last five years, the $\bar{R}^{2} s$ are increasing and relatively high in all portfolios; (ii) during the late 1990s and early 2000s the integration measure is decreasing; (iii) the integration process seems to start between 2000 and 2004; (iv) in Asia and in the Sub-Saharan areas the integration process seems to be lagged. It starts in 2006 and 2008, respectively. For the no-crises sample, I obtain the following main results: (i) emerging equity markets' performances increases as the $\bar{R}^{2}$ increases; (ii) the percentage of international excess returns' patterns explained by the first 10 principal components increases as the level of the bilateral trade between international economies increases; (iii) the degree of financial integration increases as the correlation between emerging and advanced stock market excess returns increases; (iv) financial openness increases with an increasing correlation 

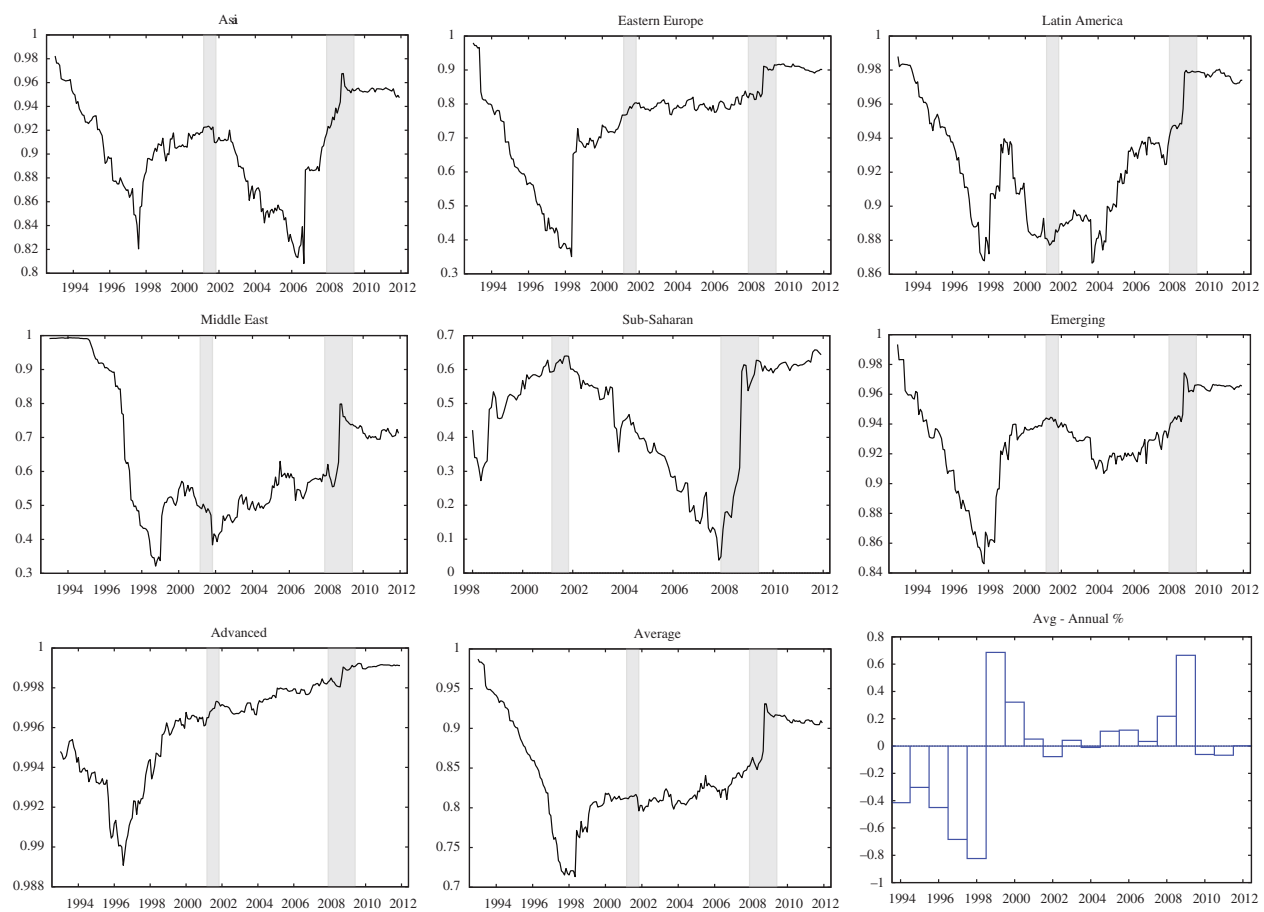

Figure 3. This figure reports the dynamics of the $\bar{R}^{2} \mathrm{f}$ or each macro area equally weighted portfolio. Equally weighted portfolios are constructed as described in Section 2. $\bar{R}^{2} s$ are obtained via OLS estimations of Equation (8). Principal components are extracted as described in Section 4.1. Estimations are performed on rolling basis using a window of 60 months. Constant is included. Standard errors are Newey and West (1987). The bottom right corner panel reports the annual rate of growth of the Average $\bar{R}^{2}$. The annual $\bar{R}^{2}$ is calculated as annual average of monthly rolling estimates. The sample goes from January 1988 (or later) until December 2011.

Note: The shaded vertical bars in all graphs denote NBER-dated recessions.

between the excess returns and the rate of change of the integration index (see Figure C.1).

Figures (D.1)-(D.7) report the dynamics of the integration process for all national stock markets. At country level, my findings are as follows. First, results suggest that most emerging national stock markets have become increasingly integrated over the last 10 years (i.e. the $\bar{R}^{2}$ seems to be increasing over time). ${ }^{16}$ I find weak integration for the following stock markets: Sri Lanka and Pakistan (i.e. the $\bar{R}^{2}$ ranges from -0.1 to 0.35 ). Second, the integration process seems to be affected by local shocks (i.e. emerging crises). In particular, for those countries that faced a strong and persistent crisis (e.g. Argentina, Brazil, Thailand, Turkey), the $\bar{R}^{2}$ is highly volatile. Third, I find a higher decrease in the level of market segmentation soon after local shocks (i.e. no-crises sample). Fourth, the joint analysis of Figures (D.1)-(D.7) and Figure A.3 confirms that the correlation between international stock markets might represent a poor measure of integration. While crosscountry correlations are increasing over time and follow a similar path, as suggested by many studies and Figure A.3, the percentage of variation in national stock market excess returns explained by the same global factors differs across countries. In other words, the increasing degree of comovement between two stock markets does not imply that they are also both increasingly integrated, that is, cross-country excess returns' patterns are not 

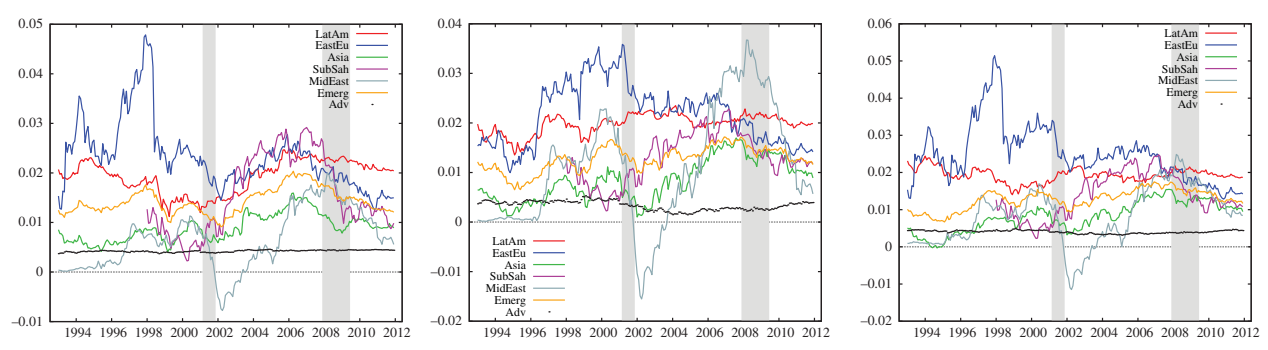

Figure 4. This figure reports the dynamics of the intercepts ('PCA Alphas') for six macro-area portfolios. The left panel reports estimates for the equal-weighted portfolio. The middle panel reports estimates for the GDP-weighted portfolio. The right panel reports estimates for the tradeweighted portfolios. Estimates are obtained using a rolling window of 60 months. Constant is included. Standard errors are Newey and West (1987). The sample goes from January 1988 (or later) until December 2011.

Note: The shaded vertical bars in all graphs denote NBER-dated recessions.

equally explained by the same global risk factors. ${ }^{17}$ Carrieri, Errunza and Hogan (2007) obtain a similar result. Using a GARCH-in-mean methodology to assess the evolution in market integration for eight emerging markets over the period 1977-2000, they find that there are substantial cross-market differences in the degree of integration.

\subsubsection{On the 'alphas'}

Figure 4 reports the dynamics of the intercept (i.e. $\alpha_{j}^{w}$ ) of Equation (8). I report estimates for the equal-, GDP- and trade-weighted macro area portfolios. Not surprisingly, emerging PCA alphas show a strong time-varying component. In contrast, the advanced portfolios' intercepts are stable over time. As suggested by Harvey (1995), the result is mainly driven by the unstable industrial structure of emerging economies. Results in Figure 4 confirm that emerging stocks tend to compensate investor with extra returns. As in Figure 2, the Jensen's alpha increases as the global integration process increases. In other words, I observe that during periods of increasing integration, both financial and real (i.e. increasing trade to GDP ratio and $\bar{R}^{2}$ ), emerging stock markets tend to generate higher unexpected excess returns. It turns that the model's validity is rarely preserved (i.e. positive and statistically different from zero alpha). In a static context, Harvey (1995) and Donadelli and Prosperi (2012), find similar results. Using a standard one-factor model (i.e. world CAPM) and a two-factor conditional model, they argue that the presence of high unexpected average excess returns suggest that variation in emerging markets stock returns might be explained by local rather than global information variables. In a partial equilibrium setup, Donadelli and Prosperi (2012) also show that the presence of additional investment costs (e.g. transaction costs) in emerging stock markets might solve the 'alpha puzzle' (i.e. the presence of high unexpected average excess returns).

\subsection{A global approach}

The idea of this exercise is to examine the dynamics of the explanatory power of a multifactor model where the factors are represented by a set of variables (i.e. principal components) aimed at explaining variation in leading global economic indicators. In practice, I extract principal components from a matrix of data containing 10 global macroeconomic indicators: JPM GERMANY CASH 6M (\$), JPM US CASH 6M (\$), 
JPM GERMAN GOVT.BOND IN US\$, JPM UNITED STATES GOVT.BOND US\$, US BENCHMARK 10 YEAR DS GOVT. INDEX - INTEREST YIELD minus US BENCHMARK 2 YEAR DS GOVT. INDEX - INTEREST YIELD (i.e. US10Y-US2Y spread), BD BENCHMARK 10 YEAR DS GOVT. INDEX - INTEREST YIELD minus BD BENCHMARK 2 YEAR DS GOVT. INDEX - INTEREST YIELD (i.e. BD10YBD2Y spread), Italy 10Y Gov. Bond Yield minus Germany 10Y Gov. Benchmark Bond (i.e. IT10Y-BD10Y spread), US Industrial Production Index (\%), Dow Jones Corporate Bond Yield and CBOE VIX. The above indicators are intended to capture the global state of the economy, and represent global volatility, international investors' risk appetite, sovereign debt risk and global liquidity conditions. ${ }^{18}$ Table 3 reports the percentage of variance explained by the first 10 principal components extracted from the two different set of variables. In the data set composed by excess returns only more than $80 \%$ of the variance is explained by the first 10 principal components (i.e. I have accounted for the vast majority of the variation in the data using 10 principal components). Not surprisingly, in the data set composed by leading global economic indicators, the variance in quasifully explained by the first six principal components (i.e. I have accounted for the vast majority of the variation in the data using the first six components).

I replicate the estimation scheme of the previous subsection using the first six principal components obtained by the data-matrix composed by the 10 global economic indicators (see Equation (9)).

$$
\operatorname{ExR}_{j, t}^{w}=\alpha_{j}^{w}+\sum_{c=1}^{6} \psi_{c}^{w} G R F_{c, t}^{w}+\varepsilon_{j, t}^{w}
$$

The dynamics of the $\bar{R}^{2}$ are illustrated in Figure 5. Estimates are reported only for the equally weighted portfolios. The results are as follows. First, the $\bar{R}^{2}$ is heavily volatile. Second, the $\bar{R}^{2}$ is relatively small. It ranges from -0.1 to 0.5 . The result suggests that the condensed set of variables used to explain variation in global economic indicators has lower explanatory power than the principal components extracted from the data-matrix composed by the 19 national stock market excess returns. Third, the integration measure sharply increases during the last crisis. The $\bar{R}^{2}$ moves really fast from values close to zero to values above 0.3 . Such result reflects the huge sensitivity of international stock markets to changes in global macro fundamentals during the subprime crises. Fourth, I find that the percent of the variance of the excess returns explained by the first six principal components increases as the degree of market openness rises. It turns out that in the nocrises period emerging markets display an increasing financial and real integration process (i.e. the $\bar{R}^{2}$ is increasing or, on average, higher).

Table 3. This table reports the percentage of variance (Var Prop.) and cumulative variance (Cum Prop.) explained by the first 10 principal components. PCA19 refers to the 10 principal components extracted from the data-matrix composed by 19 international excess returns. PCA10 refers to the 10 principal components extracted from the data-matrix composed by 10 global macro indicators. Sample: January 1988-December 2011.

\begin{tabular}{lccrrrrrrrr}
\hline Model & C1 & C2 & C3 & C4 & C5 & C6 & C7 & C8 & C9 & C10 \\
\hline PC19 (Var Prop.) & 38.9 & 11.5 & 7.0 & 5.2 & 4.4 & 4.1 & 4.0 & 3.6 & 3.0 & 2.8 \\
PC19 (Cum Prop.) & 38.9 & 50.4 & 57.4 & 62.6 & 67.0 & 71.1 & 75.1 & 78.7 & 81.7 & 84.5 \\
PC10 (Var Prop.) & 26.6 & 21.4 & 14.9 & 10.4 & 8.9 & 8.2 & 6.1 & 1.8 & 1.4 & 0.3 \\
PC10 (Cum Prop.) & 26.6 & 48.0 & 62.9 & 73.3 & 82.2 & 90.4 & 96.5 & 98.3 & 99.7 & 100.0 \\
\hline
\end{tabular}



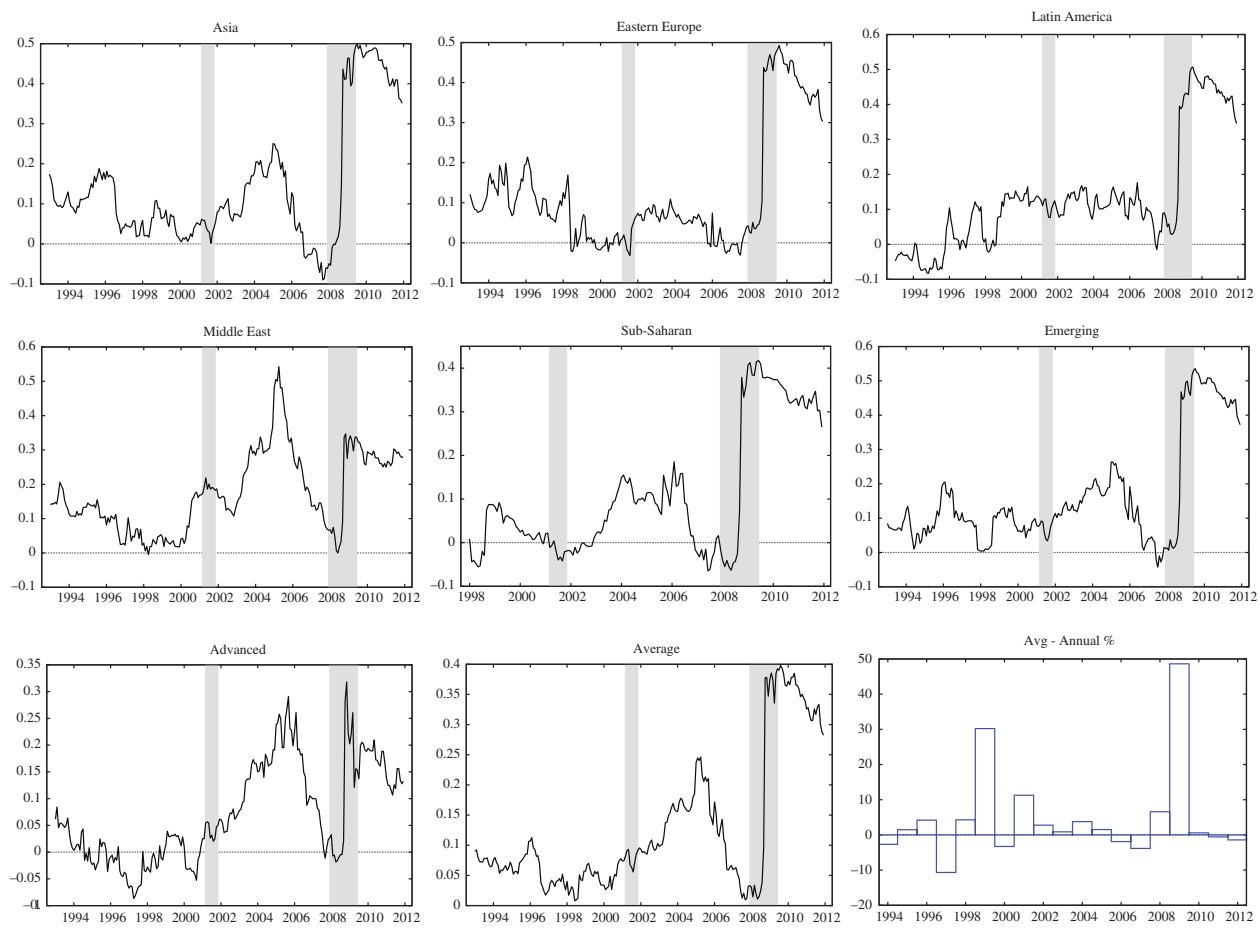

Figure 5. This figure reports the dynamics of the $\bar{R}^{2}$ for each macro area equally weighted portfolio. Equally weighted portfolios are constructed as described in Section $2 . \bar{R}^{2} s$ are obtained via OLS estimations of Equation (8). Standard errors are Newey and West (1987). Constant is included. Principal components are extracted as described in Section 4.2. Estimations are performed on rolling basis using a window of 60 months. The bottom-right corner panel reports the annual rate of growth of the average $\bar{R}^{2}$. The annual $\bar{R}^{2}$ is calculated as annual average of monthly rolling estimates. The sample goes from January 1988 (or later) until December 2011.

Note: The shaded vertical bars in all graphs denote NBER-dated recessions.

\subsection{Some final remarks}

Over the last 30 years reform and development of local securities markets have represented key strategies for a rapid economic growth in many emerging economies. For example, to develop financially integrated markets, foreign investment barriers have been lowered, country funds have been floated, and American Depositary receipts have been listed on the US market. A large number of studies show that the removal of capital controls and trade barriers in both developed countries (mostly during the 1980s) and emerging markets (mostly at the end of the 1980s and early 1990s) have led to unparalleled financial and real openness across the world. Bekaert and Harvey (2000), and Henry (2000a, 2000b), among others, document that financial market liberalizations has decreased the cost of capital in emerging markets. De Jong and De Roon (2005) argue that most of the literature treats liberalization as a one shot event and assumes that markets are completely segmented before the official liberalization date, and perfectly integrated after that date. In line with Bekaert and Harvey (1995) and Stulz (1999), the results presented in this article suggest that the process of equity market integration is gradual and takes many years with occasional reversals. Although the integration process begins with regulatory changes that can be precisely dated, such official dates do not suggest that 


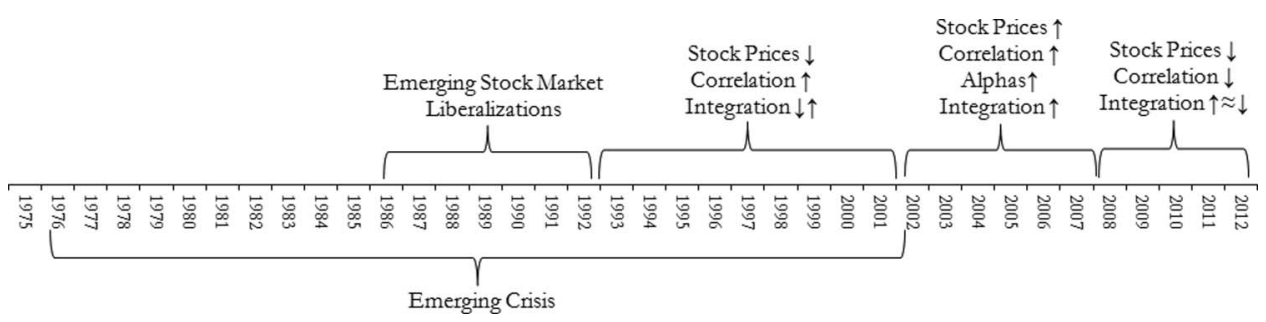

Figure 6. This figure summarizes the effects of the global integration process on the emerging market stock prices. The integration timeline reports five relevant subperiods: (i) the period in which emerging crises occurred; (ii) the period including the dates of the most important first stock market liberalizations; (iii) the post-liberalizations period; (iv) the no-crises period; (v) the 'post-Lehman' period. Date of first stock market liberalization (1986-1992): Argentina (November 1989), Brazil (March 1988), Chile (May 1987), Colombia (December 1991), India (June 1986), Korea (June 1987), Malaysia (May 1987), Mexico (May 1989), Philippines (May 1986), Taiwan (May 1986), Thailand (January 1988), Venezuela (January 1990). Crisis dates (1976-2002): Argentina (19801982, 1989-1990, 1995, 2001-2002), Brazil (1990, 1994-1999), Chile (1976, 1981-1983), Colombia (1982-1987, 1998-2001), Egypt (19801983), Hungary (1991-1995), Indonesia (19972002), Israel (1977-1983), Korea (1997-2002), Malaysia (1997-2001), Mexico (1981-1991, 19942000), Morocco (1980-1982), Peru (1983-1990), Philippines (1983-1987, 1997-2002), Poland (1992-1995), Sri Lanka (1989-1993), Thailand (1983-1987, 1997-2002), Turkey (1982-1985, 2000-2002), Venezuela (1994-1995). Legend: $\uparrow=$ increasing path, $\downarrow=$ decreasing path, $\approx=$ stable path. First stock market liberalization dates are from Henry (2000a) and emerging crisis dates are from Joyce (2011).

the market has become integrated (see Bekaert, 1995). My estimates suggest also that the local shocks of the late 1990s and early 2000s have largely affected emerging stock market prices as well as the global integration process. The timeline depicted in Figure 6 summarizes some of my findings on the impact of financial and real market openness on the behaviour of emerging national stock market prices (i.e. realized excess returns).

\section{Conclusion}

The study of the effect of financial openness on emerging stock markets has recently received much interest in a variety of literatures, especially in international finance and empirical asset pricing. Common results are: (i) stock market liberalizations allow for risk sharing between domestic and foreign agents; (ii) stock market liberalizations reduce the aggregate cost of capital; (iii) given constant expected future cash flows, stock market liberalizations should increase countries' equity price indexes; (iv) given the lower cost of capital, stock market liberalizations should increase physical investment (e.g. FDI). Most of these studies employ pre-2005 data and do not provide a dynamic analysis. It turns out that such empirical findings might have been influenced by the emerging crises of the late 1990s and early 2000s. Using data running from January 1988 (or later) to December 2011, this paper studies the effects of the global integration process on emerging stock market excess returns in a dynamic context. My results suggest that stock market liberalizations and de facto global integration do not show up simultaneously. While stock market liberalization can be classified as on shot event, global market integration is a gradual process. Using the trade to GDP ratio as a measure of real integration and the $\bar{R}^{2}$ obtained from a multi-(non-traded) factor asset-pricing model as a measure of financial integration, I show that the de facto and the de jure integration processes are not synchronized. While stock market liberalizations took place in the late 1980s and early 
1990s, an increasing de facto integration seems to start in the early 2000s. In contrast to existing studies, the dynamics of the emerging stock excess returns suggest that stock market liberalizations have lowered countries' equity price indexes. The result is consistent both across macro-area portfolios and national stock markets. I argue that such findings are mainly driven by local shocks (i.e. emerging crises). In addition, over the period bounded by the last two recessions, I find that realized and unexpected excess returns in emerging stock markets increase as the global integration and the financial markets' comovement increase. Finally, I confirm two key results: (i) financial integration is accompanied by economic integration; (ii) the dynamics of the correlation between international stock markets represents a weak measure of financial integration.

\section{Acknowledgements}

I am indebted to Alessia Varani and Paolo Vitale. I thank an anonymous referee, Nicola Borri, Lauren Persha and Lorenzo Prosperi for their suggestions. I also gratefully acknowledge comments from seminar participants at LUISS Guido Carli, UNC at Chapel Hill, Toulouse School of Economics, International Conference in Applied Business and Economics at University of Piraeus (Athens) and 1st PhD Student Conference in International Macroeconomics and Financial Econometrics at Université Parìs Ouest. All errors are the author's responsibility.

\section{Notes}

1. For a detailed discussion on emerging crises, see Joyce (2011).

2. For example, in Panchenko and $\mathrm{Wu}$ (2009), the sample period goes from January 1995 to December 2005, and in De Jong and De Roon (2005) it runs from January 1988 (or later) to May 2000. Pukthuanthong and Roll (2009) employ data running from January 1973 (or later) to February 2008. In contrast, my sample period goes from January 1988 (or later) to December 2011.

3. For a detailed discussion on the de jure and the de facto integration, see Bekaert, Harvey, Lundblad and Siegel (2009).

4. A similar argument can be found in Carrieri, Errunza and Hogan (2007) and Kritzam et al. (2011).

5. I justify the choice of monthly data as follows: (i) the choice is based on a desire to avoid missing daily data in the time series as well as the time zone issue; (ii) the monthly frequency is also motivated by the need to match macroeconomic variables' frequency.

6. Similar results can be found in Bekaert et al. (1998), Estrada (2000) and Grootveld and Salomons (2003), among many others.

7. The IMF database does not provide the Czech Republic Gross Domestic Product series for the years 1990-1994. To complete the series, I borrow the Czech Republic Gross Domestic Product from the OECD data library. OECD GDP is denominated in US\$ at current prices and at current exchange rates.

8. Gross domestic product, current prices (US\$): values are based upon GDP in national currency converted to US\$ using market exchange rates (yearly averages). Source: IMF.

9. For the UKthe last observation corresponds to June 2011. Therefore, from July 2011 to December 2011 the UK trade share is assumed to be constant and equal to the last available observation.

10. Gross domestic product - expenditure approach (millions of US\$, current prices, current PPPs, annual levels, seasonally adjusted). The OECD Total covers the following 34 OECD Member countries: Australia, Austria, Belgium, Canada, Chile, Czech Republic, Denmark, Estonia, Finland, France, Germany, Greece, Hungary, Iceland, Ireland, Israel, Italy, Japan, Korea, Luxembourg, Mexico, Netherlands, New Zealand, Norway, Poland, Portugal, Slovak Republic, Slovenia, Spain, Sweden, Switzerland, Turkey, United Kingdom and United States. Source: OECD.

11. All time series are $I(0)$. The $\mathrm{ADF}$ test for $\left[\left(R_{m, t}-R_{t}^{f}\right) \cdot\left(\right.\right.$ GlobIntIndex $\left.\left._{t-1}\right)\right]$ rejects the null hypothesis of a unit root (i.e. the series is stationary). The test is available upon request. 
12. For a detailed discussion on stock markets liberalizations, see Bekaert and Harvey (1995, 1997, 2000).

13. Similar results can be found in De Jong and De Roon (2005) and Donadelli and Prosperi (2012).

14. Pukthuanthong and Roll (2009) estimate the covariance matrix for each calendar year using daily data from 1973 to 2006. Once eigenvectors are computed and sorted from the largest to the smallest eigenvalue, they estimate principal components from return in the subsequent calendar year (e.g. the weightings (eigenvectors) computed from the 1973 covariance matrix are applied to the returns during 1974).

15. Note that all national stock indexes are total return indexes (i.e. I use only MSCI TRI to compute returns). Donadelli and Prosperi (2012) point out that price indexes (i.e. MSCI PI) might generate different returns.

16. The limited amount of data does not allow us to make robust comments on the following African stock markets: Kenya, Nigeria, Morocco and Tunisia.

17. Using industrial stock market indices, Donadelli (2013) obtains a similar result.

18. A similar set of variables reflecting global economic conditions can be found in Ciarlone, Piselli and Trebeschi (2007).

\section{Notes on contributor}

Michael Donadelli is currently a PhD Candidate in Economics at LUISS Guido Carli in Rome (Italy), and visiting scholar at the University of North Carolina at Chapel Hill (Department of Finance). He is also research fellow at the Arcelli Centre for Monetary and Financial Studies. His research interests are empirical asset pricing, international macro-finance and poor economics. $\mathrm{He}$ received an MSc in Economics from LUISS Guido Carli in 2011; received an International Master in Economics and Finance from the University of Venice, Italy, in 2008; received a MSc in Economics in Finance from the University of Venice in 2007; and received a BSc in Economics and Finance from the University of Venice in 2005.

\section{References}

Bekaert, G. 1995. Market integration and investment barriers in emerging equity markets. World Bank Economic Review 9: 75-107.

Bekaert, G., B.E. Claude, C.R. Harvey, and T.E. Viskanta. 1998. Distributional characteristics of emerging market returns and asset allocation. Journal of Portfolio Management Winter: 102-16.

Bekaert, G., and C.R. Harvey. 1995. Time-varying world market integration. Journal of Finance 50: 403-44.

Bekaert, G., and C.R. Harvey. 1997. Emerging equity market volatility. Journal of Financial Economics 43: 29-78.

Bekaert, G., and C.R. Harvey. 2000. Capital flows and the behavior of emerging market equity returns, NBER chapters, in: Capital Flows and the Emerging Economies: Theory, Evidence, and Controversies, pp. 159-194. National Bureau of Economic Research, Inc.

Bekaert, G., and C.R. Harvey. 2002. Research in emerging market finance: looking to the future. Emerging Markets Review 3: 429-48.

Bekaert, G., C.R. Harvey, and C. Lundblad. 2003. Equity market liberalization in emerging markets. The Journal of Financial Research 26(3): 275-99.

Bekaert, G., C.R. Harvey, C. Lundblad, and S. Siegel. 2009. What segments equity markets? NBER Working Paper No. 14802.

Bekaert, G., R.J. Hodrick, and X. Zhang. 2009. International stock return comovements. Journal of Finance 54(6): 2591-626.

Bilson, C.M., T.J. Brailsford, and V.J. Hooper. 2001. Selecting macroeconomic variables as explanatory factors of emerging stock market returns. Pacific-Basin Finance Journal 9: 401-26.

Carrieri, F., V. Errunza, and K. Hogan. 2007. Characterizing world market integration through time. Journal of Financial and Quantitative Analysis 42(4): 915-40.

Chari, A., and P.B. Henry. 2004. Risk sharing and asset prices: Evidence from a natural experiment. Journal of Finance 59(3): 1295-324. 
Ciarlone, A., P. Piselli, and G. Trebeschi. (2007). Emerging markets spreads and global financial conditions. Temi di discussione, Banca d'Italia, n. 637.

Colacito, R., and M.M. Croce. 2010. The short- and long-run benefits of financial integration. American Economic Review: Papers \& Proceeding 100(2): 527-31.

Corsetti, G., M. Pericoli, and M. Sbracia. 2005. Some contagion, some Interdependence: more pitfalls in tests of financial contagion. Journal of International Money and Finance 24(8): $1177-99$.

De Jong, F., and F.A. De Roon. 2005. Time varying market integration and expected returns in emerging markets. Journal of Financial Economics 78: 583-613.

Donadelli, M. 2013. On the dynamics of industrial stock market excess returns, CASMEF Working Paper Series n. 2013/02.

Donadelli, M., and L. Prosperi. 2012. On the role of liquidity in emerging markets stock prices. Research in Economics 66(4): 320-48.

Edison, H., and F. Warnock. 2002. A simple measure of the intensity of capita controls. Unpublished working paper, International Monetary Fund.

Edison, H., and F. Warnock. 2003. A simple measure of the intensity of capital controls. Journal of Empirical Finance 10(1): 81-103.

Errunza, V., and P. Pabmanabhan. 1988. Further evidence on the benefits of portfolio investments in emerging markets. Financial Analysts Journal 44: 76-8.

Estrada, J. 2000. The cost of equity in emerging markets: A downside risk approach. Emerging Markets Quarterly 4: 19-30.

Gau, Y.F., H. Mingshu, and W.L. Wu. 2010. International asset allocation for incompletely-informed investors. Journal of Financial Markets 3: 422-47.

Grootveld, H., and R. Salomons. 2003. The equity risk premium: Emerging vs. developed markets. Emerging Markets Review 4(2): 121-44.

Harvey, C. 1993. Portfolio enhancement using emerging markets and conditioning information, World Bank Discussion Papers, 228, December, 110-44.

Harvey, C.R. 1995. Predictable risk and returns in emerging markets. Review of Financial Studies 8: $773-816$.

Henry, P. 2000a. Stock market liberalization, economic reform and emerging market equity prices. Journal of Finance 55: 529-64.

Henry, P. 2000b. Do stock market liberalization cause investment booms? Journal of Financial Economics 58: 301-34.

Hodrick, R., and E.C. Prescott. 1997. Postwar U.S. business cycles: an empirical investigation. Journal of Money, Credit, and Banking 29(1): 116.

Joyce, J.P. 2011. Financial globalization and banking crises in emerging markets. Open Economies Review 22: 875-95.

Kritzam, M., Y. Li, S. Page, and R. Rigobon. 2011. Principal components as a measure of systemic risk. Journal of Portfolio Management 37(4): 112-26.

Levine, R., and S. Zervos. 1996. Stock market development and long-run growth. The World Bank Economic Review 10(2): 323-39.

Liao, W., and A.M. Santacreu. (2012). The trade comovement puzzle and the margins of international trade. Unpublished manuscript.

Newey, W.K., and K.D. West. 1987. A simple, positive semi-definite, heteroskedasticity and autocorrelation consistent covariance matrix. Econometrica 55(3): 703-8.

Panchenko, V., and E. Wu. 2009. Time-varying market integration and stock and bond return concordance in emerging markets. Journal of Banking \& Finance 33: 1014-21.

Pukthuanthong, K., and R. Roll. 2009. Global market integration: An alternative measure and its application. Journal of Financial Economics 92(2): 214-32.

Santacreu, A.M. (2011). Innovation, diffusion and trade: theory and measurement. NYU mimeo.

Stulz, R. 1995. The cost of capital in internationally integrated markets: The case of Nestlé. European Financial Management 1(1): 11-22.

Stulz, R. 1999. International portfolio flows and security markets, in Mart. In International Capital Flows, ed. M. Feldstein, 257-93. Chicago, IL: University of Chicago Press. 


\section{Appendix A}

\section{A.1. Data description and summary statistics}

Table A.1. Data summary. MSCI TRI (U\$) are downloaded for the following list of countries: Canada, France, Germany, Italy, Japan, UK, USA, Argentina, Brazil, Chile, Colombia, Mexico, Peru, Czech Rep, Hungary, Poland, Russia, Turkey, China, India, Indonesia, Korea, Malaysia, Pakistan, Philippines, Sri Lanka, Taiwan, Thailand, Kenya, Nigeria, South Africa, Egypt, Jordan, Morocco, Tunisia. The MSCI sample goes from January 1988 (or later) to December 2011. The VIX and the Dow Jones Corporate Bond Yield are calculated as monthly averages of daily data. Additional Notes: The 'IT 10Y-BD 10Y spread' is calculated as the difference between the Italy 10Y Government Bond Yield and the Germany 10Y Benchmark Bond. The following differences: (US BENCHMARK 10 YEAR DS GOVT. INDEX - INTEREST YIELD) - (US BENCHMARK 2 YEAR DS GOVT. INDEX - INTEREST YIELD) and (BD BENCHMARK 10 YEAR DS GOVT. INDEX - INTEREST YIELD) - (BD BENCHMARK 2 YEAR DS GOVT. INDEX - INTEREST YIELD) provide the US 10Y-US $2 \mathrm{Y}$ and BD 10Y-BD 2Y spreads, respectively.

\begin{tabular}{|c|c|c|c|}
\hline Series & Source & Frequency & Sample \\
\hline $\begin{array}{l}\text { MSCI TOTAL RETURN INDEX } \\
\text { (U\$) }\end{array}$ & Datastream & Monthly & Jan 88-Dec 11 \\
\hline One-month Treasury bill rate & $\begin{array}{l}\text { Kenneth R. French Data } \\
\text { Library }\end{array}$ & Monthly & Jan 88-Dec 11 \\
\hline Mkt-Rf (Market Factor) & $\begin{array}{l}\text { Kenneth R. French Data } \\
\text { Library }\end{array}$ & Monthly & Jan 88-Dec 11 \\
\hline GDP, current prices, US\$ & $\begin{array}{l}\text { International Monetary } \\
\text { Funds }\end{array}$ & Annual & 1987-2010 \\
\hline $\begin{array}{l}\text { Gross domestic product, expenditure } \\
\text { approach, US\$, current prices, cur- } \\
\text { rent PPPs, annual levels, SA }\end{array}$ & OECD Stats & Quarterly & Q41987-Q32011 \\
\hline $\begin{array}{l}\text { Export of Goods (United States } \\
\text { Dollars) }\end{array}$ & Global Financial Data & Monthly & Jan 88-Dec 11 \\
\hline Imports of Goods (US\$) & Global Financial Data & Monthly & Jan 88-Dec 11 \\
\hline $\begin{array}{l}\text { JPM GERMANY CASH 6M (\$) - } \\
\text { TOT RETURN IND (U\$) }\end{array}$ & Global Financial Data & Monthly & Jan 88-Dec 11 \\
\hline $\begin{array}{l}\text { JPM US CASH 6M (\$) - TOT RET- } \\
\text { URN IND (U\$) }\end{array}$ & Global Financial Data & Monthly & Jan 88-Dec 11 \\
\hline $\begin{array}{l}\text { PM GERMAN GOVT. BOND IN } \\
\text { US\$ - TOT RETURN IND (U\$) }\end{array}$ & Global Financial Data & Monthly & Jan 88-Dec 11 \\
\hline $\begin{array}{l}\text { JPM ITALY GOVT. BOND IN US\$ - } \\
\text { TOT RETURN IND (U\$) }\end{array}$ & Global Financial Data & Monthly & Jan 88-Dec 11 \\
\hline $\begin{array}{l}\text { JPM UNITED STATES GOVT. } \\
\text { BOND US\$ - TOT RETURN IND } \\
\text { (U\$) }\end{array}$ & Global Financial Data & Monthly & Jan 88-Dec 11 \\
\hline $\begin{array}{l}\text { US BENCHMARK } 10 \text { YEAR DS } \\
\text { GOVT. INDEX INTEREST } \\
\text { YIELD }\end{array}$ & Global Financial Data & Monthly & Jan 88-Dec 11 \\
\hline $\begin{array}{l}\text { BD BENCHMARK } 10 \text { YEAR DS } \\
\text { GOVT. INDEX INTEREST } \\
\text { YIELD }\end{array}$ & Global Financial Data & Monthly & Jan 88-Dec 11 \\
\hline $\begin{array}{l}\text { US BENCHMARK } 2 \text { YEAR DS } \\
\text { GOVT. INDEX INTEREST } \\
\text { YIELD }\end{array}$ & Global Financial Data & Monthly & Jan 88-Dec 11 \\
\hline $\begin{array}{l}\text { BD BENCHMARK } 2 \text { YEAR DS } \\
\text { GOVT. INDEX INTEREST } \\
\text { YIELD }\end{array}$ & Global Financial Data & Monthly & Jan 88-Dec 11 \\
\hline Italy $10 \mathrm{Y}$ Government Bond Yield & Global Financial Data & Monthly & Jan 88-Dec 11 \\
\hline
\end{tabular}


Table A.1. (Continued).

\begin{tabular}{lllc}
\hline Series & \multicolumn{1}{c}{ Source } & Frequency & Sample \\
\hline $\begin{array}{l}\text { Germany 10Y Benchmark Bond } \\
\text { United States Industrial Production } \\
\text { Index (Index 2002 = 100, SA) }\end{array}$ & Global Financial Data & Monthly & Jan 88-Dec 11 \\
$\begin{array}{l}\text { Dow Jones Corporate Bond Yield } \\
\text { CBOE S\&P 500 Volatility Index } \\
\text { (VIX) }\end{array}$ & Global Financial Data & Monthly & Jan 88-Dec 11 \\
& & Monthly & Jan 88-Dec 11 \\
\hline
\end{tabular}

Table A.2. Monthly summary statistics: National Stock Market Excess Returns. Excess returns are computed as in Equation (2). All data are based on monthly observations denominated in US\$. Means, standard deviations, and min, max and median values are all expressed in percentage points. The sample period is from January 1988 (or later) until December 2011. Data availability: Colombia, Peru, Poland, China, India Pakistan, Sri Lanka and South Africa (from January 1993); Czech Republic, Hungary, Russia and Egypt (from January 1995); Kenya and Nigeria (from June 2002); Morocco and Tunisia (from June 2004).

\begin{tabular}{|c|c|c|c|c|c|c|c|c|}
\hline Country & Mean & $\mathrm{SD}$ & $\mathrm{ShR}$ & Max & Min & Median & Kurt & Skew \\
\hline \multicolumn{9}{|c|}{ Emerging Economies } \\
\hline Argentina & 2.15 & 15.85 & 0.14 & 95.05 & -58.40 & 1.05 & 9.46 & 1.66 \\
\hline Brazil & 2.40 & 15.04 & 0.16 & 79.95 & -67.19 & 2.28 & 4.85 & 0.25 \\
\hline Chile & 1.41 & 7.25 & 0.19 & 21.65 & -33.04 & 1.44 & 2.33 & -0.46 \\
\hline Colombia & 1.58 & 9.75 & 0.16 & 30.30 & -40.85 & 1.66 & 1.62 & -0.24 \\
\hline Mexico & 1.76 & 9.55 & 0.18 & 28.47 & -47.64 & 2.21 & 3.13 & -0.79 \\
\hline Peru & 1.70 & 9.77 & 0.17 & 37.58 & -51.56 & 2.18 & 4.96 & -0.45 \\
\hline Czech Rep. & 1.27 & 9.53 & 0.13 & 35.83 & -51.77 & 1.06 & 5.37 & -0.76 \\
\hline Hungary & 1.51 & 12.00 & 0.13 & 45.74 & -62.24 & 1.76 & 4.82 & -0.56 \\
\hline Poland & 1.77 & 14.40 & 0.12 & 117.07 & -52.74 & 1.31 & 18.23 & 2.10 \\
\hline Russia & 2.34 & 16.41 & 0.14 & 60.69 & -61.07 & 2.30 & 2.63 & -0.03 \\
\hline Turkey & 1.90 & 16.71 & 0.11 & 72.61 & -49.38 & 1.34 & 2.07 & 0.54 \\
\hline China & 0.28 & 10.78 & 0.03 & 46.44 & -43.06 & 0.24 & 2.87 & 0.33 \\
\hline India & 0.91 & 8.99 & 0.10 & 32.46 & -40.67 & 1.39 & 1.64 & -0.24 \\
\hline Indonesia & 1.69 & 14.74 & 0.11 & 93.79 & -45.78 & 1.03 & 9.52 & 1.57 \\
\hline Korea & 0.92 & 11.20 & 0.08 & 59.72 & -47.15 & 0.11 & 3.92 & 0.43 \\
\hline Malaysia & 0.74 & 8.05 & 0.09 & 38.57 & -30.61 & 1.15 & 3.53 & -0.02 \\
\hline Pakistan & 0.84 & 11.27 & 0.07 & 36.01 & -38.13 & 0.05 & 1.68 & -0.05 \\
\hline Philippines & 0.77 & 9.66 & 0.08 & 43.07 & -36.82 & 0.72 & 2.35 & 0.22 \\
\hline Sri Lanka & 0.80 & 10.59 & 0.08 & 60.15 & -25.58 & -0.16 & 6.74 & 1.50 \\
\hline Taiwan & 0.72 & 10.62 & 0.07 & 46.21 & -34.33 & 0.7 & 1.63 & 0.25 \\
\hline Thailand & 1.03 & 11.47 & 0.09 & 60.73 & -41.97 & 1.27 & 4.02 & 0.32 \\
\hline Kenya & 2.05 & 9.29 & 0.22 & 24.44 & -33.93 & 1.81 & 1.68 & -0.42 \\
\hline Nigeria & 1.17 & 9.97 & 0.12 & 41.70 & -37.37 & 0.46 & 3.15 & 0.14 \\
\hline South Africa & 1.12 & 8.43 & 0.13 & 33.77 & -44.81 & 1.29 & 4.73 & -0.75 \\
\hline Egypt & 1.40 & 9.68 & 0.14 & 37.17 & -33.37 & 0.65 & 1.45 & 0.41 \\
\hline Jordan & 0.07 & 5.49 & 0.01 & 22.39 & -24.88 & -0.43 & 2.79 & -0.05 \\
\hline Morocco & 1.15 & 6.40 & 0.18 & 19.49 & -23.84 & 0.72 & 2.37 & -0.42 \\
\hline Tunisia & 1.08 & 5.72 & 0.19 & 21.23 & -20.94 & 0.92 & 3.54 & 0.03 \\
\hline \multicolumn{9}{|c|}{ Advanced Eco } \\
\hline France & 0.56 & 6.10 & 0.0 & 20. & -22.26 & 0.92 & 0.75 & -0.28 \\
\hline Germany & 0.57 & 6.59 & 0.09 & 19.62 & -22.83 & 1.31 & 1.02 & -0.43 \\
\hline
\end{tabular}


Table A.2. (Continued).

\begin{tabular}{lrrrrcrrr}
\hline Country & Mean & \multicolumn{1}{c}{ SD } & ShR & Max & Min & Median & Kurt & Skew \\
\hline Italy & 0.26 & 7.29 & 0.04 & 27.29 & -23.54 & 0.24 & 0.98 & 0.10 \\
Japan & -0.12 & 6.79 & -0.02 & 23.58 & -23.99 & 0.14 & 0.75 & 0.04 \\
United Kingdom & 0.44 & 5.15 & 0.09 & 17.23 & -23.24 & 0.53 & 1.64 & -0.27 \\
United States & 0.56 & 4.34 & 0.13 & 13.50 & -20.07 & 1.05 & 1.90 & -0.63 \\
Canada & 0.65 & 5.61 & 0.12 & 17.15 & -34.22 & 1.06 & 5.44 & -0.94 \\
Avg. (Emerging) & 1.30 & 10.66 & 0.12 & 47.94 & -42.11 & 1.09 & 4.18 & 0.16 \\
Avg. (Advanced) & 0.42 & 5.98 & 0.08 & 19.85 & -24.31 & 0.75 & 1.78 & -0.35 \\
\hline
\end{tabular}

Source: Datastream.

Table A.3. Monthly summary statistics: Macro Area Portfolio Excess Returns. Excess returns are computed as in Equation (2). Equal-, GDP- and trade-weighted portfolios are constructed as defined in Equations (3)-(5). Means, standard deviations, and min, max and median values are all expressed in percentage points. Statistics are computed using monthly observations denominated in US\$. The sample goes from January 1988 (or later) to December 2011.

\begin{tabular}{|c|c|c|c|c|c|c|c|}
\hline Portfolios & Latin & Eastern & Asia & Sub-Sah & North Africa & Emerging & Advanced \\
\hline & America & Europe & Far-East & Africa & Mid-East & (All) & (G7) \\
\hline \multicolumn{8}{|c|}{ Equally weighted } \\
\hline Mean & 2.04 & 1.91 & 0.95 & 1.10 & 0.51 & 1.41 & 0.42 \\
\hline StDev & 8.37 & 13.55 & 7.07 & 7.36 & 5.13 & 6.44 & 4.91 \\
\hline ShR & 0.24 & 0.14 & 0.13 & 0.15 & 0.10 & 0.22 & 0.08 \\
\hline Max & 27.74 & 72.61 & 21.60 & 21.16 & 18.20 & 19.75 & 17.09 \\
\hline Min & -47.42 & -55.44 & -33.39 & -30.90 & -25.76 & -38.98 & -24.31 \\
\hline Median & 1.85 & 1.80 & 1.09 & 1.51 & 0.31 & 2.06 & 0.83 \\
\hline Kurtosis & 4.60 & 4.87 & 2.55 & 3.03 & 2.95 & 5.93 & 2.46 \\
\hline Skewness & -0.69 & 0.72 & -0.50 & -0.77 & -0.29 & -1.16 & -0.56 \\
\hline \multicolumn{8}{|c|}{ GDP-weighted } \\
\hline Mean & 2.06 & 1.84 & 0.84 & 0.97 & 0.94 & 1.33 & 0.37 \\
\hline StDev & 10.28 & 14.27 & 7.94 & 7.55 & 7.30 & 7.28 & 4.54 \\
\hline ShR & 0.20 & 0.13 & 0.11 & 0.13 & 0.13 & 0.18 & 0.08 \\
\hline Max & 49.27 & 72.61 & 27.70 & 26.06 & 34.76 & 23.64 & 15.66 \\
\hline Min & -49.80 & -56.38 & -41.21 & -33.51 & -28.22 & -40.55 & -22.30 \\
\hline Median & 2.35 & 0.90 & 1.03 & 1.67 & 0.05 & 1.51 & 0.78 \\
\hline Kurtosis & 4.02 & 3.43 & 2.91 & 3.29 & 3.00 & 4.21 & 2.34 \\
\hline Skewness & -0.34 & 0.48 & -0.41 & -0.68 & 0.67 & -0.73 & -0.59 \\
\hline \multicolumn{8}{|c|}{ Trade-weighted } \\
\hline Mean & 1.97 & 1.94 & 0.81 & 0.98 & 0.95 & 1.23 & 0.42 \\
\hline StDev & 8.90 & 13.96 & 7.96 & 7.52 & 5.76 & 7.45 & 4.77 \\
\hline ShR & 0.22 & 0.14 & 0.10 & 0.13 & 0.17 & 0.16 & 0.09 \\
\hline Max & 31.18 & 72.61 & 25.79 & 26.43 & 22.83 & 20.95 & 16.41 \\
\hline Min & -48.49 & -56.23 & -40.36 & -31.16 & -25.47 & -43.99 & -23.05 \\
\hline Median & 2.33 & 1.26 & 1.30 & 1.54 & 0.50 & 1.87 & 0.88 \\
\hline Kurtosis & 4.04 & 3.98 & 2.84 & 3.04 & 2.39 & 5.10 & 2.32 \\
\hline Skewness & -0.86 & 0.56 & -0.42 & -0.64 & 0.13 & -1.03 & -0.61 \\
\hline
\end{tabular}

Source: Datastream, IMF and OECD. 


\section{A.2. International stock markets: some stylized facts}
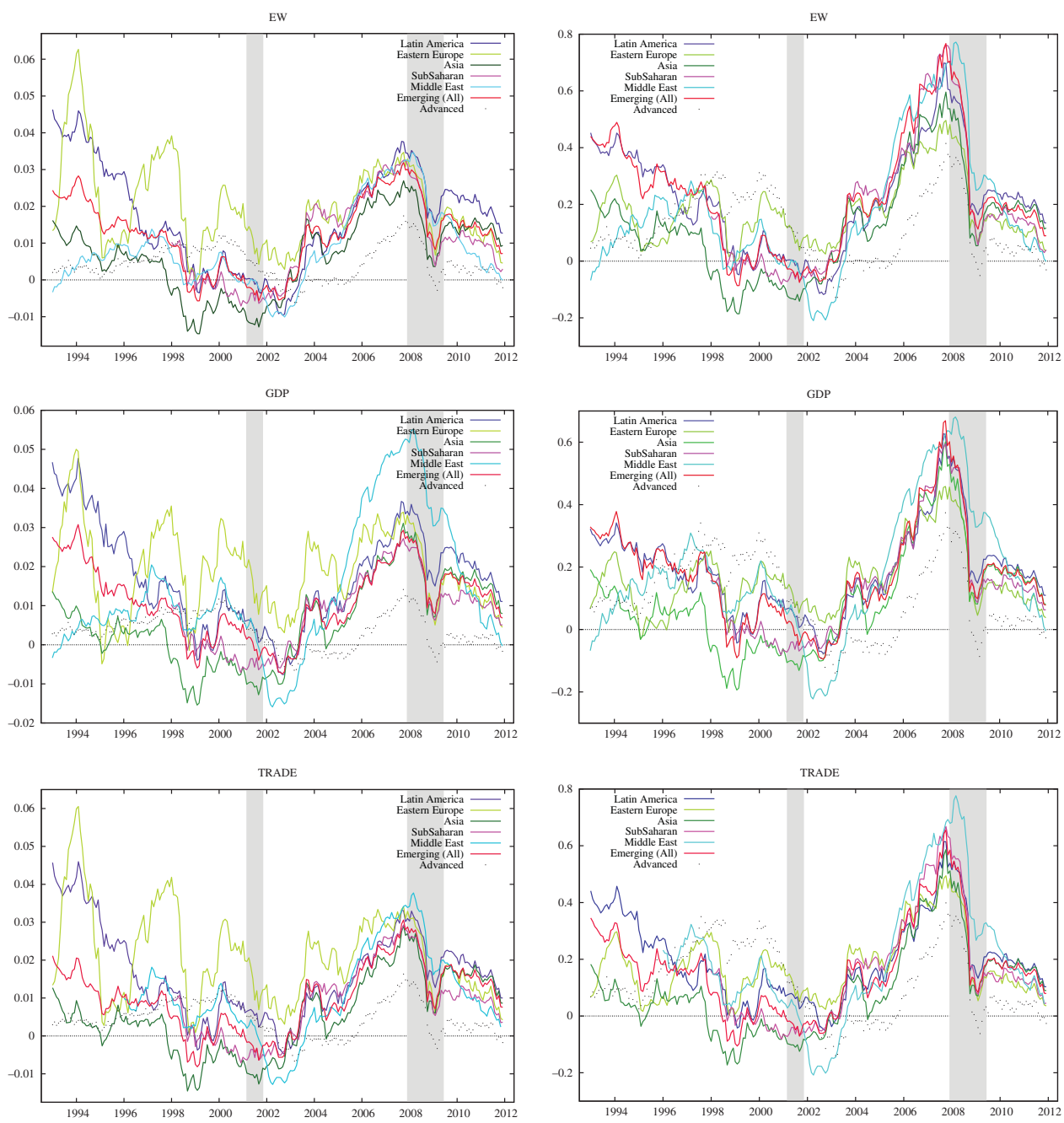

Figure A.1. This figure reports the means (left panel) and the Sharpe ratios (right panel) for seven macro area equal-, GDP- and trade-weighted portfolio excess returns. Equal-, GDP- and tradeweighted portfolios are constructed as defined in Equations (3)-(5). Estimates are computed on rolling basis using a window of 60 months. The sample goes from January 1988 (or later) until December 2011.

Note: The shaded vertical bars in all graphs denote NBER-dated recessions.

Source: Datastream, IMF and Global Financial Data. 

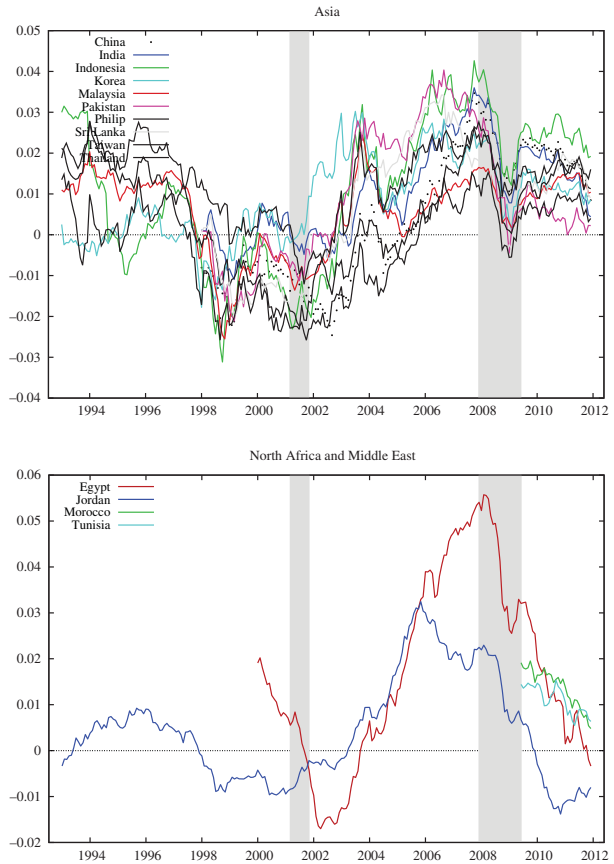

Sub-Saharan

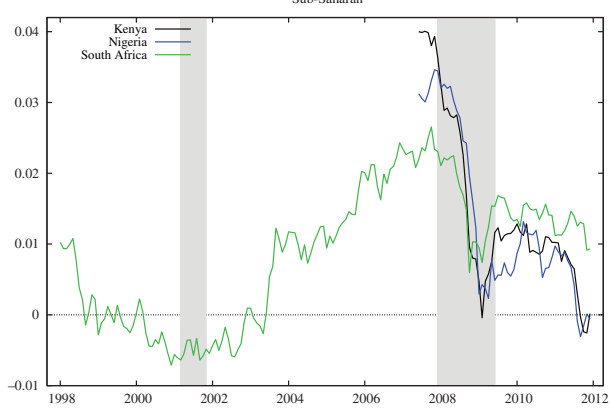

Eastern Europe

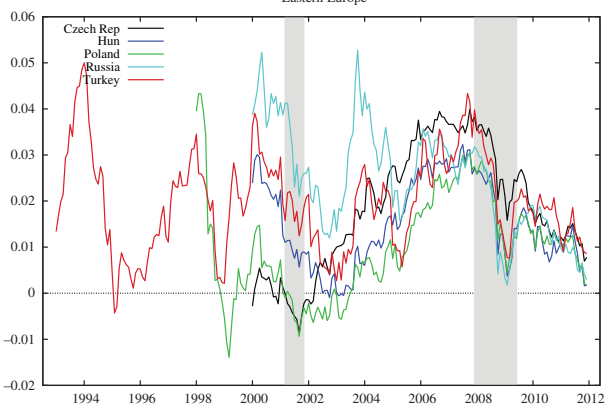

Latin America

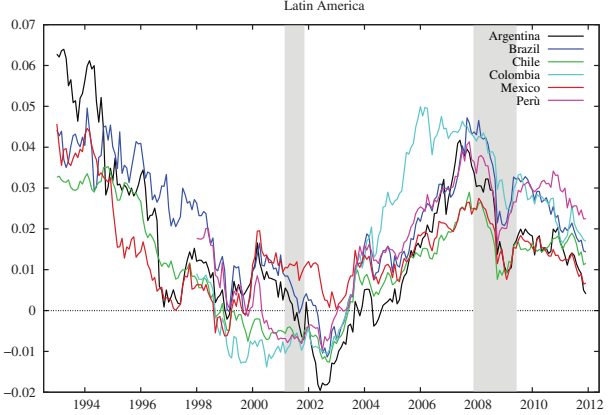

Advanced (G7)

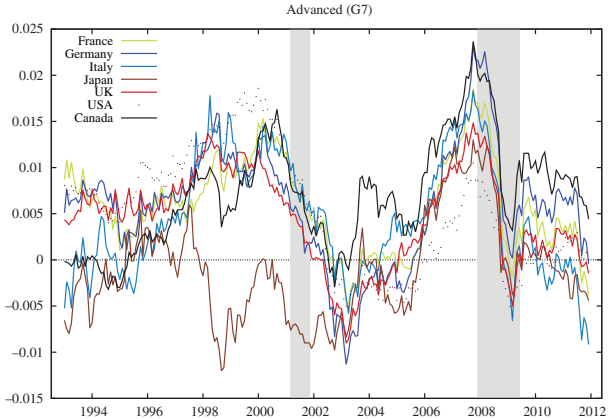

Figure A.2. This figure reports the mean values for 28 emerging and 7 advanced national stock market excess returns. Average excess returns are computed on rolling basis using a window of 60 months. The sample goes from January 1988 (or later) until December 2011.

Note: The shaded vertical bars in all graphs denote NBER-dated recessions. 

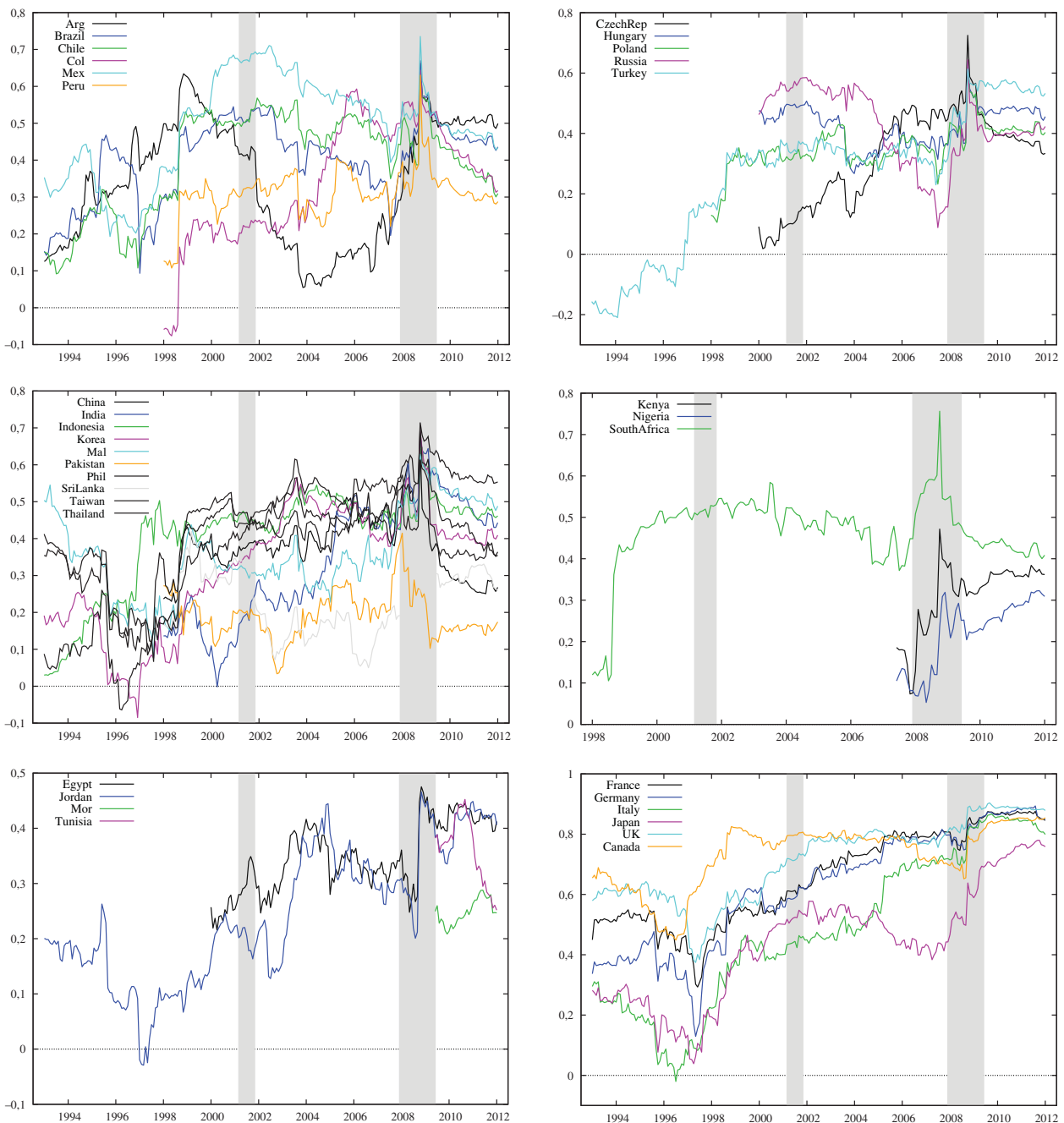

Figure A.3. This figure reports the correlation coefficients between the international stock market excess returns and the US stock market excess return. Coefficients are computed on rolling basis using a window of 60 months. The sample is from January 1988 (or later) until December 2011. Note: The shaded vertical bars in all graphs denote NBER-dated recessions. 


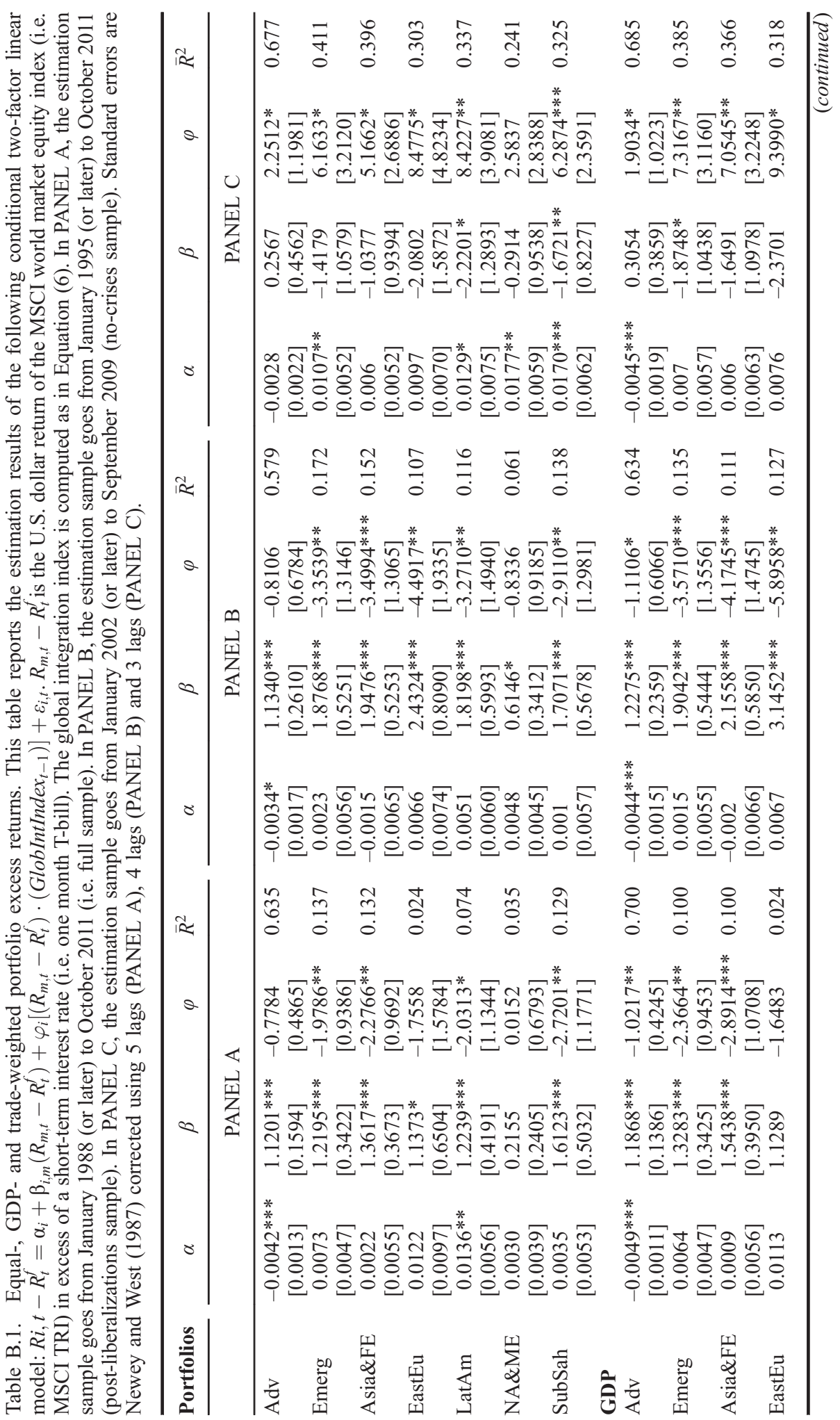




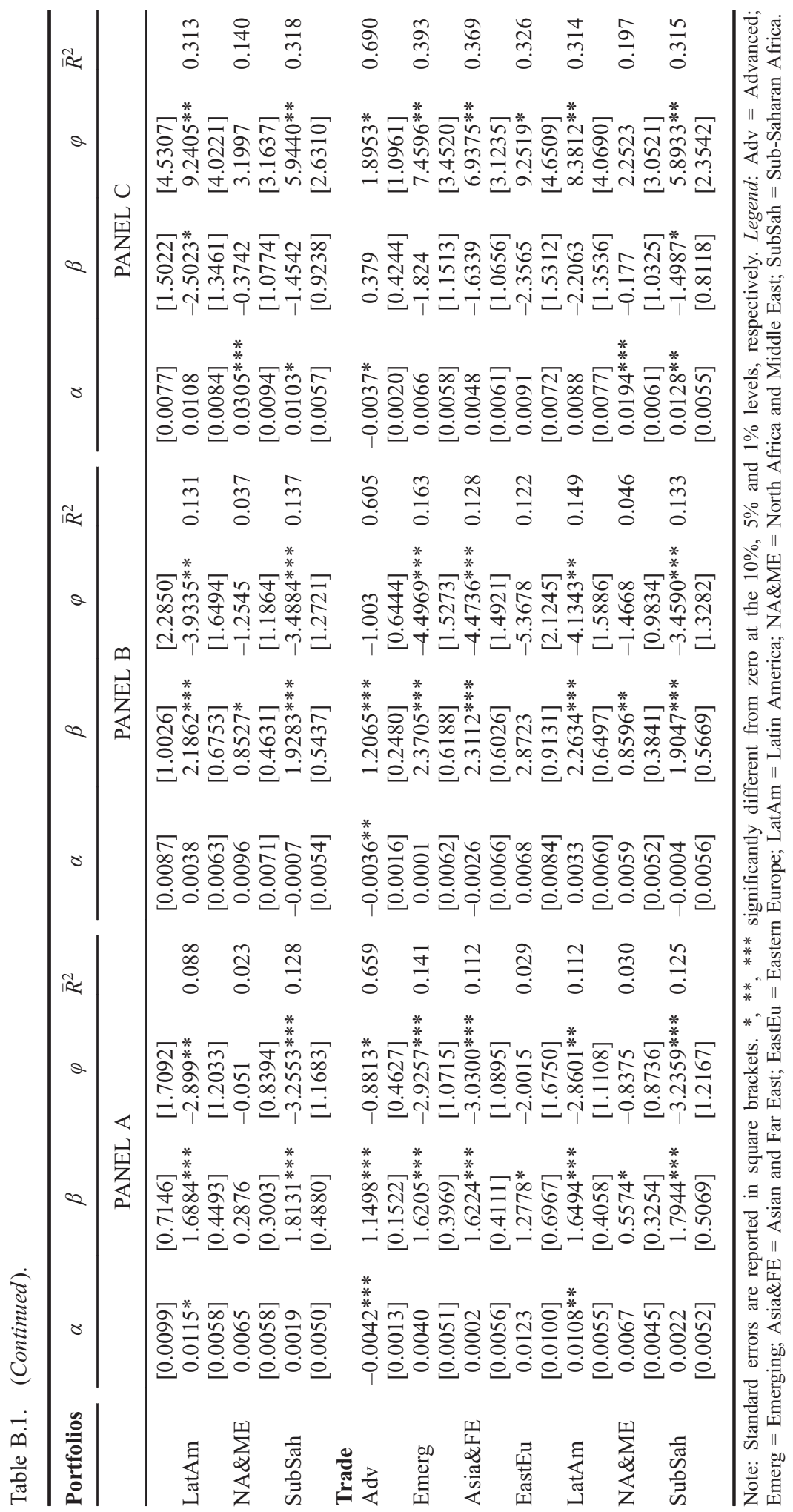




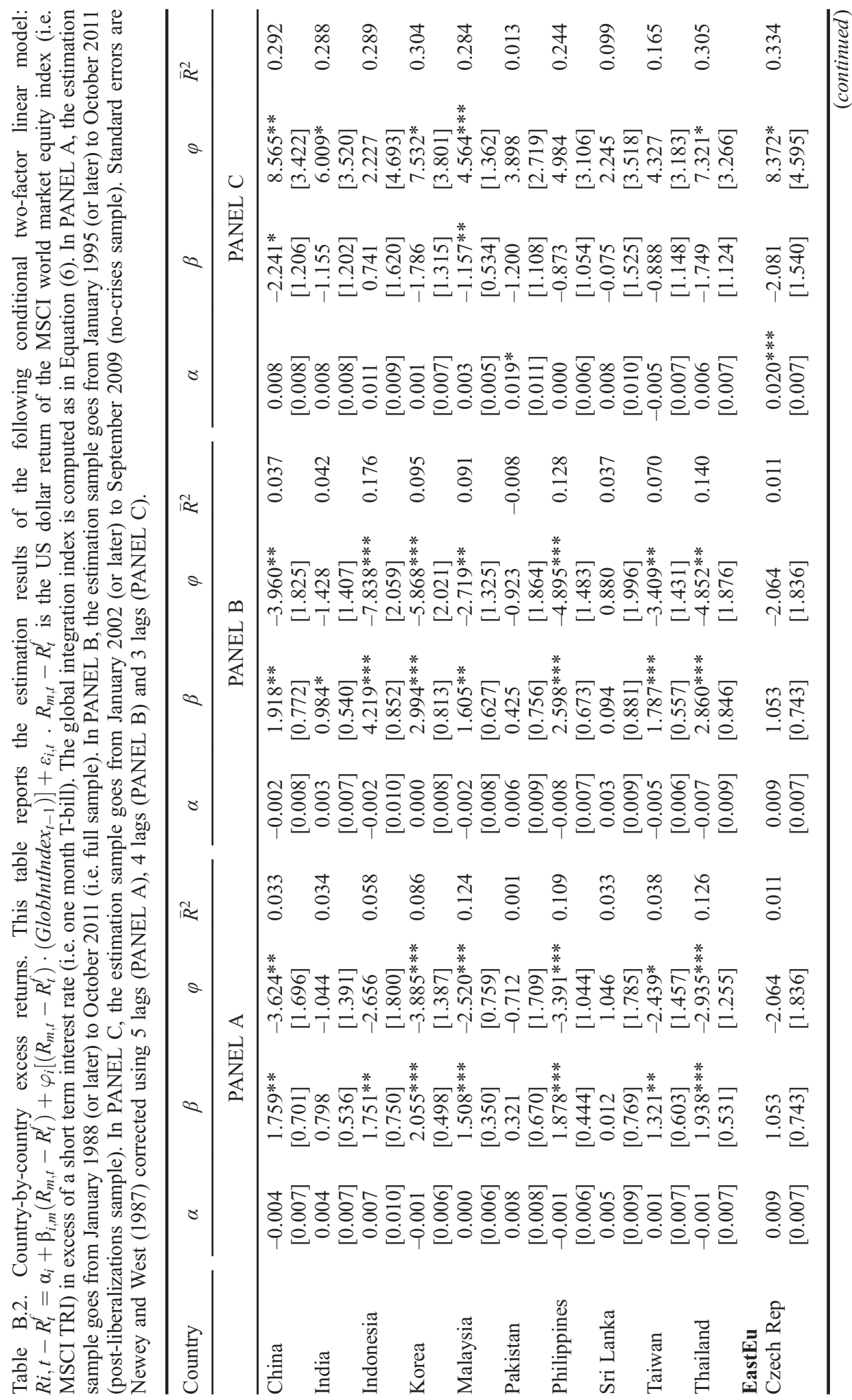




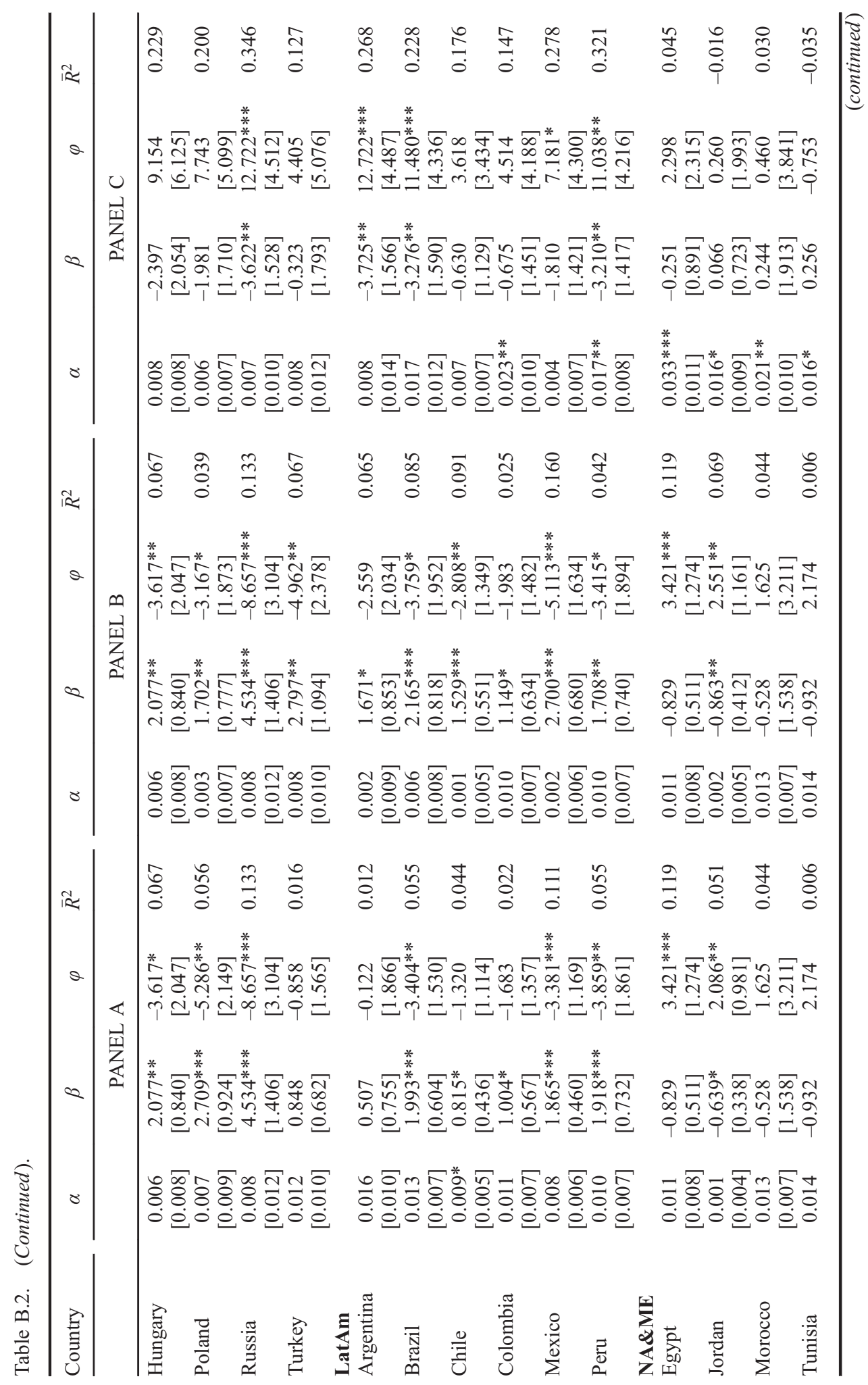




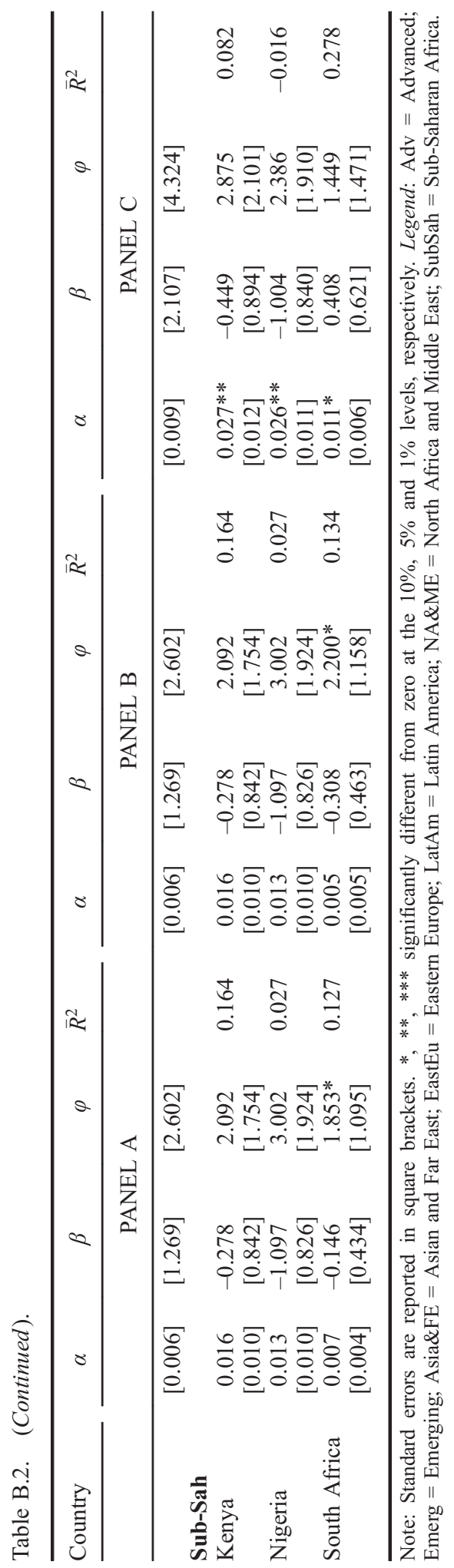




\section{Appendix C}

\section{C.1. Market openness and international excess returns}
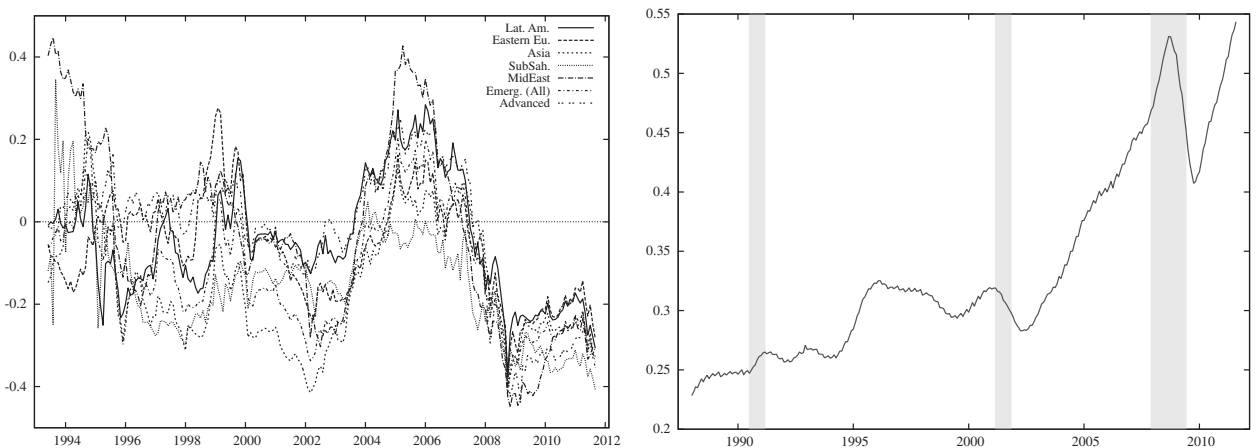

Figure C.1. Rolling correlation coefficients between portfolio excess returns and Global Integration Index (left panel). Coefficients are computed on rolling basis using a window of 60 months. The right panel plots the Global Integration Index (see Equation (6)). The sample runs from January 1988 to August 2011.

Note: The shaded vertical bars denote NBER-dated recessions.

Source: Datastream, IMF and Global Financial Data.

\section{Appendix D}

\section{D.1. The country-by-country}

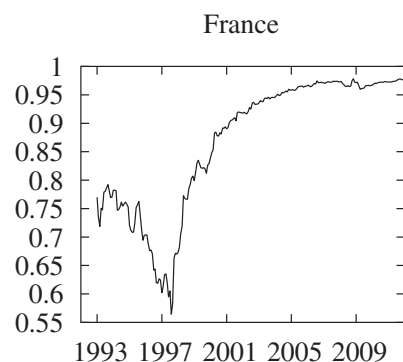

UK

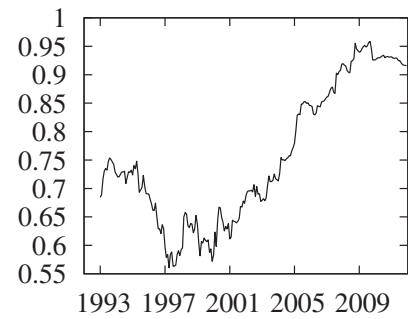

Germany

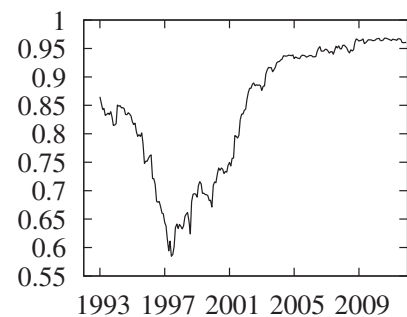

US

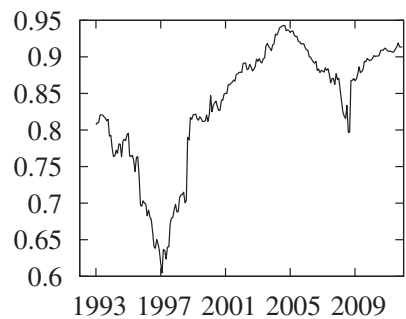

Italy

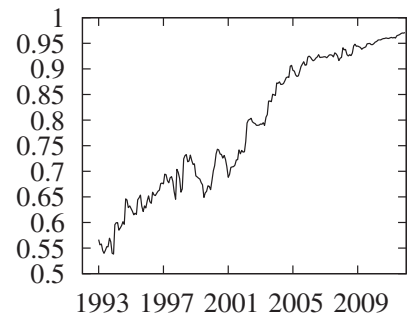

Canada

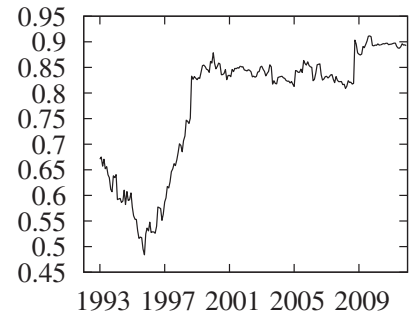

Figure D.1. Europe and North America. This figure reports the dynamics of the $\bar{R}^{2}$ for the European and North American national stock markets. The $\bar{R}^{2} s$ are obtained by estimating Equation (8) in an OLS framework. Principal components are extracted as described in section 5. Estimations are performed on rolling basis using a window of 60 months. Standard errors are Newey and West (1987). Constant is included. The sample goes from January 1988 (or later) until December 2011. 


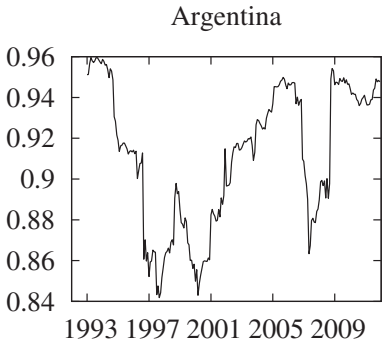

Colombia

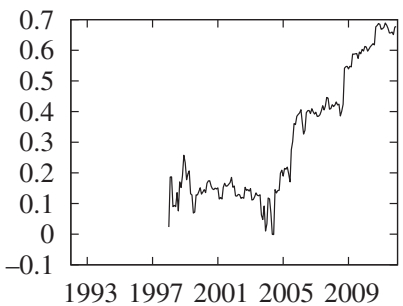

Brazil

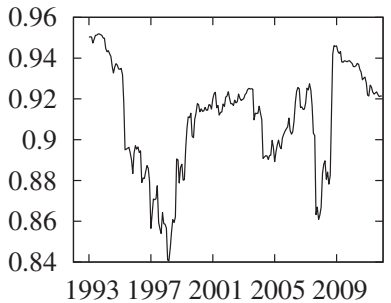

Mexico

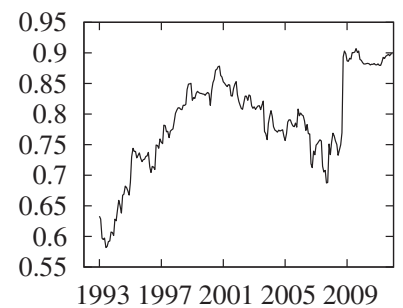

Chile

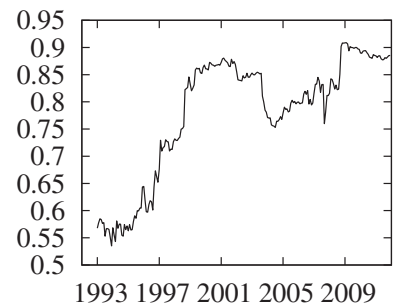

Peru

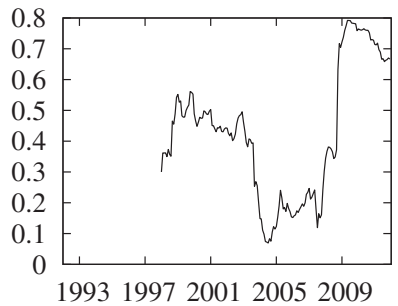

Figure D.2. Latin America. This figure reports the dynamics of the $\bar{R}^{2}$ for the Latin American national stock markets. The $\bar{R}^{2} s$ are obtained by estimating Equation (8) in an OLS framework. Principal components are extracted as described in Section 5. Estimations are performed on rolling basis using a window of 60 months. Standard errors are Newey and West (1987). Constant is included. The sample goes from January 1988 (or later) until December 2011.

CzechRep

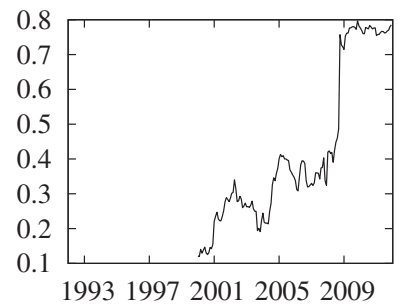

Russia

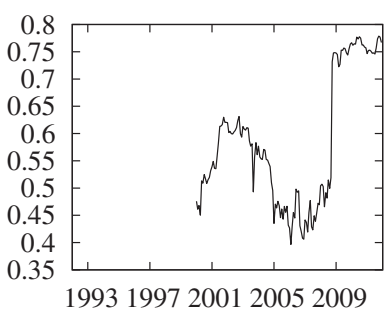

Hungary

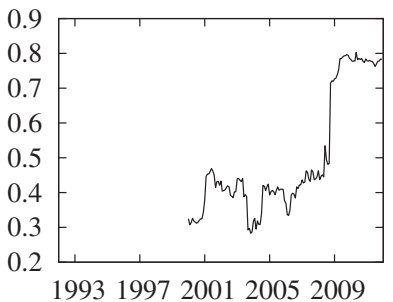

Turkey

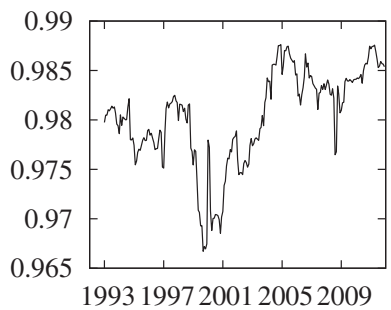

Poland

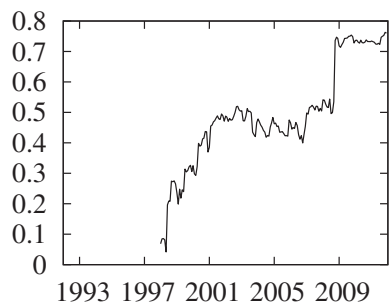

Jordan

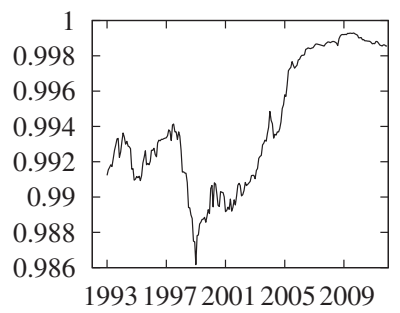

Figure D.3. East Europe. This figure reports the dynamics of the $\bar{R}^{2}$ for the East European national stock markets. The $\bar{R}^{2} s$ are obtained by estimating Equation (8) in an OLS framework. Principal components are extracted as described in Section 5. Estimations are performed on rolling basis using a window of 60 months. Standard errors are Newey and West (1987). Constant is included. The sample goes from January 1988 (or later) until December 2011. 

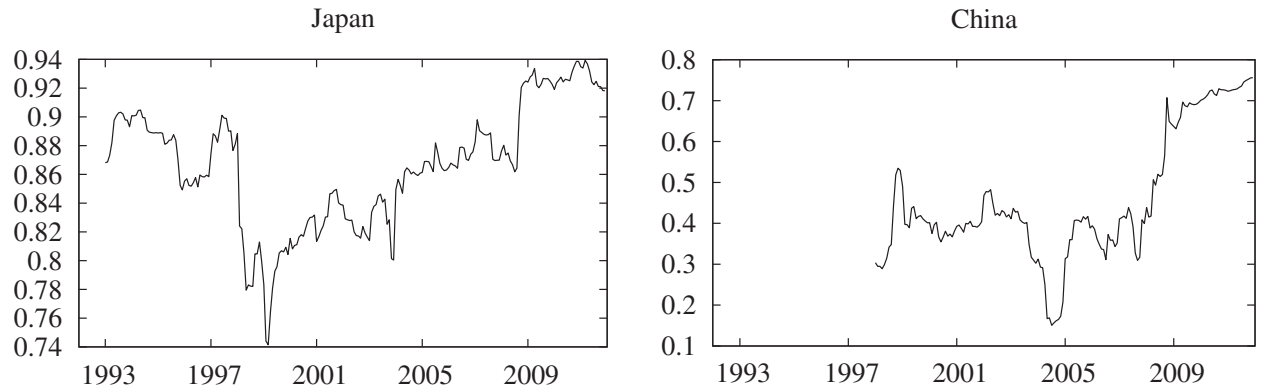

Korea
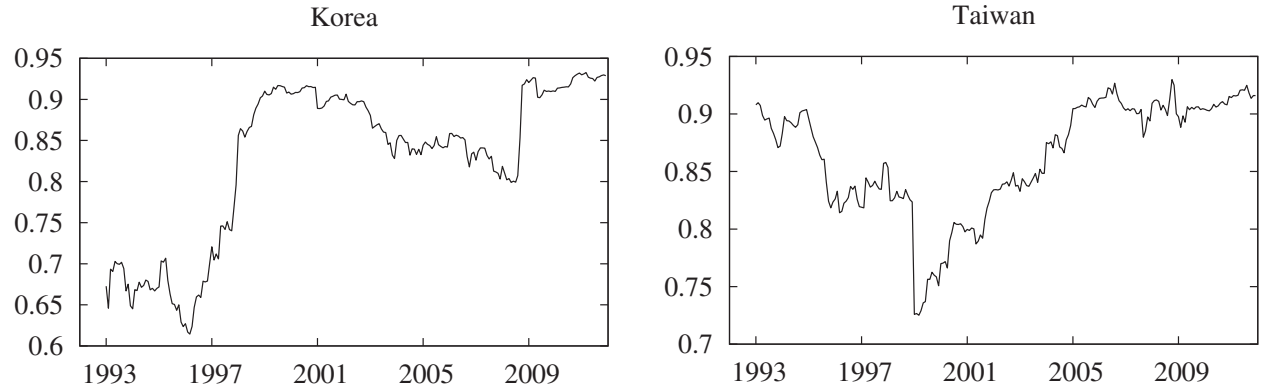

Figure D.4. East Asia. This figure reports the dynamics of the $\bar{R}^{2}$ for the East Asian national stock market. The $\bar{R}^{2} s$ are obtained by estimating Equation (8) in an OLS framework. Principal components are extracted as described in section 5. Estimations are performed on rolling basis using a window of 60 months. Standard errors are Newey and West (1987). Constant is included. The sample goes from January 1988 (or later) until December 2011.
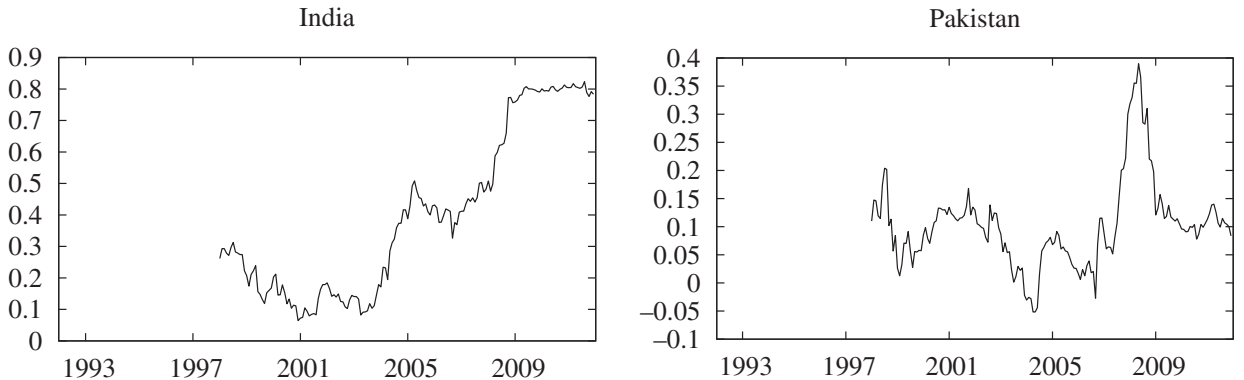

SriLanka

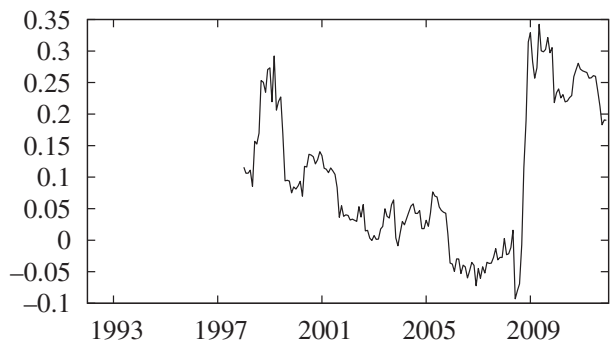

Figure D.5. South Asia. This figure reports the dynamics of the $\bar{R}^{2}$ for the South Asian national stock markets. The $\bar{R}^{2} s$ are obtained by estimating Equation (8) in a OLS framework. Principal components are extracted as described in section 5. Estimations are performed on rolling basis using a window of 60 months. Standard errors are Newey and West (1987). Constant is included. The sample goes from January 1988 (or later) until December 2011. 
Indonesia

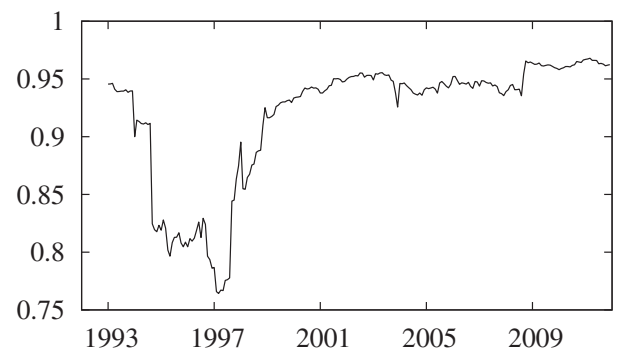

Philippines

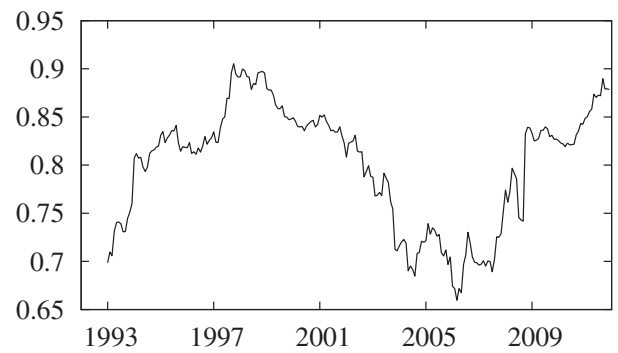

Malaysia

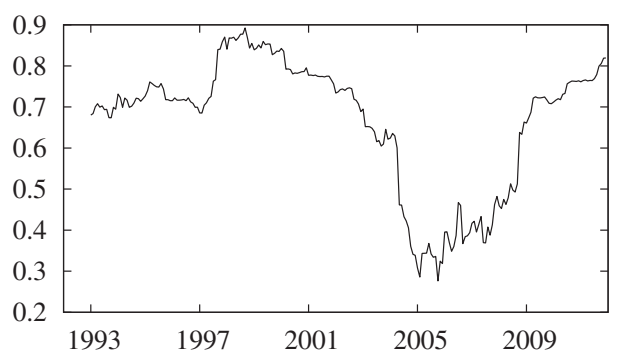

Thailand

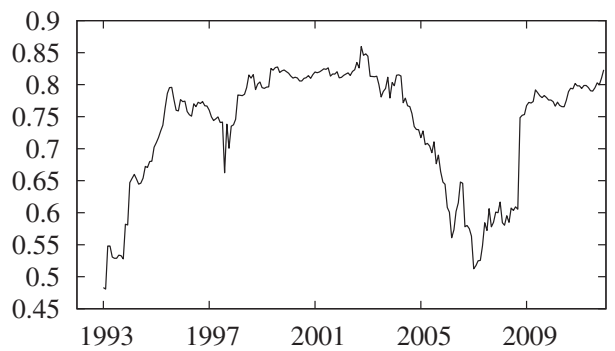

Figure D.6. SouthEast Asia. This figure reports the dynamics of the $\bar{R}^{2}$ for Southeast Asian national stock markets. The $\bar{R}^{2} s$ are obtained by estimating Equation (8) in an OLS framework. Principal components are extracted as described in section 5. Estimations are performed on rolling basis using a window of 60 months. Standard errors are Newey and West (1987). Constant is included. The sample goes from January 1988 (or later) until December 2011.

Kenya

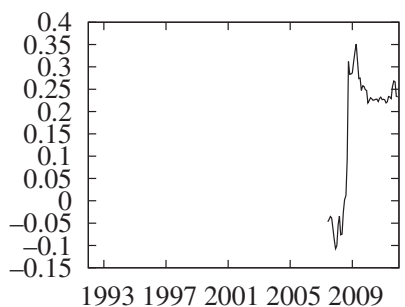

Egypt

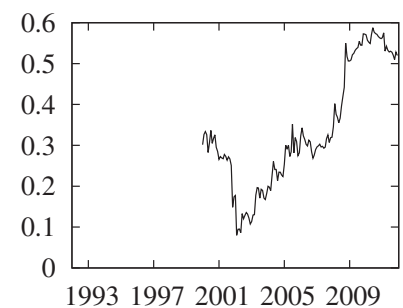

Nigeria

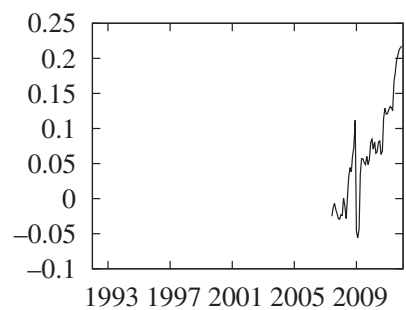

Morocco

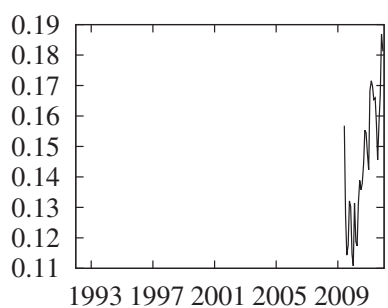

SouthAfrica

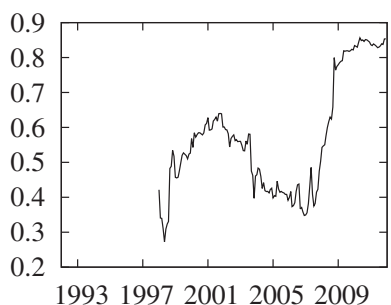

Figure D.7. Africa. This figure reports the dynamics of the $\bar{R}^{2}$ for the African national stock markets. The $\bar{R}^{2} s$ are obtained by estimating Equation (8) in an OLS framework. Principal components are extracted as described in Section 5. Estimations are performed on rolling basis using a window of 60 months. Standard errors are Newey and West (1987). Constant is included. The sample goes from January 1988 (or later) until December 2011. 